\title{
Rhodium-Catalyzed Dimerization of Terminal Alkynes Assisted by MeI
}

\author{
Chrong-Ching Lee, Ying-Chih Lin,* Yi-Hung Liu, and Yu Wang \\ Department of Chemistry, National Taiwan University, Taipei, Taiwan 106, Republic of China
}

Received June 3, 2004

\begin{abstract}
Dimerization of terminal arylalkynes at ambient temperature catalyzed by $\mathrm{Rh}(\mathrm{CO})\left(\mathrm{PPh}_{3}\right)_{2^{-}}$ $\mathrm{Cl}$ (2) in the presence of MeI leads to formation of enyne with high conversion and high regio- and stereoselectivity. A rhodium intermediate captured from oxidative addition of MeI was used for dimerization of alkyne with selectivity controlled by the use of solvents. In aprotic solvent (such as acetone, $\mathrm{CH}_{2} \mathrm{Cl}_{2}$, or THF) dimerization of terminal alkynes $\mathrm{HC} \equiv \mathrm{C}\left(p-\mathrm{C}_{6} \mathrm{H}_{4} \mathrm{X}\right)\left(\mathbf{1}, \mathrm{X}=\mathrm{H}, \mathbf{a} ; \mathrm{NO}_{2}, \mathbf{b} ; \mathrm{C}(\mathrm{O}) \mathrm{H}, \mathbf{c} ; \mathrm{Me}, \mathbf{d} ; \mathrm{CN}, \mathbf{e} ; \mathrm{NMe}_{2}, \mathbf{f} ; \mathrm{CF}_{3}, \mathbf{g} ; \mathrm{F}, \mathbf{h} ; \mathrm{Br}, \mathbf{i}\right.$; $\mathrm{I}, \mathbf{j})$ leads to the $(E)$-1,4-disubstituted enynes $\mathbf{6}(\mathbf{a}-\mathbf{k})$ in high selectivity. However, when $\mathrm{MeOH}$ is used as a solvent, the dimerization of 1-arylalkynes containing an electronwithdrawing group affords selectively the $(Z)$-1,4-disubstituted enyne $\mathbf{8}$. Requirement of the presence of $\mathrm{MeI}$ for this conversion indicates that the process presumably involves initially a six-coordinated rhodium methylacetylide intermediate. Oxidative addition of $\mathrm{ICH}_{2} \mathrm{CN}$ to 2 yielded the catalytically inactive six-coordinated complex $\mathrm{Rh}(\mathrm{CO})\left(\mathrm{PPh}_{3}\right)_{2}(\mathrm{C} \equiv \mathrm{CPh})(\mathrm{I})\left(\mathrm{CH}_{2^{-}}\right.$ $\mathrm{CN})(\mathbf{5 a})$. The analogous complex $\mathbf{5 b}$ with a $p$-nitro group on the phenyl acetylide ligand is characterized by X-ray diffraction analysis.
\end{abstract}

\section{Introduction}

Alkyne-coupling reactions catalyzed by transition metals are of considerable current interest because these reactions afford unsaturated four-carbon compounds such as conjugated enynes, which are important building blocks ${ }^{1}$ for synthetic organic chemistry and key units found in a variety of biologically active compounds. Many metal complexes including early, late transition metals and lanthanide series such as $\mathrm{Sc},{ }^{2} \mathrm{Y},{ }^{3} \mathrm{Ce},{ }^{3} \mathrm{La},{ }^{3}$ $\mathrm{Sm},{ }^{4} \mathrm{Zr},{ }^{5} \mathrm{Ti}, \mathrm{Cr},{ }^{6}$ and $\mathrm{Ru},{ }^{7} \mathrm{Rh},{ }^{8} \mathrm{Ni},{ }^{9} \mathrm{Pd},{ }^{10}$ and $\mathrm{Cu}^{11}$ have been used in the dimerization reaction of terminal alkynes; however, in most cases a mixture of regio- and

(1) (a) Trost, B. M. Science 1991, 254, 1471. (b) Nicolaou, K. C.; Dai W. M.; Tsay, S. C.; Estevez, V. A.; Wrasidlo, W. Science 1992, 256, 1172. (c) Trost, B. M. Angew. Chem., Int. Ed. Engl. 1995, 34, 259. (d) Modern Acetylene Chemistry; Stang, P. J., Diederich, F., Eds.; VCH: New York, 1995. (e) Henkelmann, J. In Applied Homogeneous Catalysis with Organometallic Compounds; Cornils, B., Herrman, W. A., Eds.; VCH: New York, 1996. (f) Hubner, H.; Haubmann, C.; Utz, W.; Gmeiner, P. J. Med. Chem. 2000, 43, 756. (g) Siemsen, P.; Livingston, R. C.; Diederich, F. Angew. Chem., Int. Ed. 2000, 39, 2632. (h) Esteruelas, M. A.; Herrero, J.; López, A. M.; Oliván, M. Organometallics 2001, 20, 3202. (i) Yang, C.; Nolan, S. P. J. Org. Chem. 2002, 67, 591. (j) Melis, K.; Samulkiewicz, P.; Rynkowski, J.; Verpoort, F. Tetrahedron Lett. 2002, 43, 2713. (k) Katayama, H.; Nakayama, M.; Nakano, T.; Wada, C.; Akamatsu, K.; Ozawa, F. Macromolecules 2004, 37, 13.

(2) (a) Thompson, M. E.; Baxter, S. M.; Bulls, A. R.; Burger, B. J.;

Nolan, M. C.; Santarsiero, B. D.; Schadfer, W. P.; Bercaw, J. E. J. Am. Chem. Soc. 1987, 109, 203. (b) Claire, M.; Schaefer, W. P.; Bercaw, J. E. Organometallics 1991, 10, 525 .

(3) (a) Heeres, H. J.; Teuben, J. H. Organometallics 1991, 10, 1980. (b) Duchateau, R.; van Wee, C. T.; Teuben, J. H. Organometallics 1996 , 15, 2291. (c) Dash, A. K.; Gourevich, I.; Wang, J. Q.; Wang, J.; Kapon, M.; Eisen, M. S. Organometallics 2001, 20, 5084. (d) Nishiura, M.; Hou, Z.; Wakatsuki, Y.; Yamaki, T.; Miyamoto, T. J. Am. Chem. Soc. 2003 , $125,1184$.

(4) Evans, W. J.; Keyer, R. A.; Ziller, J. W. Organometallics 1993, $12,2618$.

(5) Horton, A. D. J. Chem. Soc., Chem. Commun. 1992, 185

(6) (a) Hagihara, N.; Tamura, M.; Yamazaki, H.; Fujiwara, M. Bull. Chem. Soc. Jpn. 1961, 34, 892. (b) Akita M.; Yasuda, H.; Nakamura, A. Bull. Chem. Soc. Jpn. 1984, 57, 480. stereoisomeric enynes ( $E, Z$-form and head-to-tail dimers) is obtained.

The factors that affect regio- and stereoselectivity depend mainly on the electronic effects and steric hindrance at the alkyne substituent and at the coordination sphere of the metal. Methods for selective construction of head-to-tail enynes in the presence of the Pd system were developed by Trost. ${ }^{12}$ The homocoupling and cross-coupling of acetylenes were achieved

(7) (a) Sasaki, Y.; Dixneuf, P. H. J. Chem. Soc., Chem. Commun. 1986, 790. (b) Bianchini, C.; Peruzzini, M.; Zanobini, F.; Frediani, P.; Albinati, A. J. Am. Chem. Soc. 1991, 113, 5453. (c) Echevarren, A. M. Lopez, J.; Santos, A.; Montoya, J. J. Organomet. Chem. 1991, 414, 393. (d) Dhlenburg, L.; Frosin, K.-M.; Kerstan, S.; Werner, D. J. Organomet. Chem. 1991, 407, 115. (e) Wakatsuki, Y.; Yamazaki, H.; Kumegawa, N.; Satoh, T.; Satoh, J. Y. J. Am. Chem. Soc. 1991, 113, 9604. (f) Yi, C. S.; Liu, N. Organometallics 1996, 15, 3968. (g) Field, L. D.; Messerle, B. A.; Smernik, R. J.; Hambley, T. W.; Turner, P. J. Chem. Soc., Dalton Trans. 1999, 2577.

(8) (a) Ohshita, J.; Furumori, K.; Matsuguchi, A.; Ishikawa, M. $J$. Org. Chem. 1990, 55, 3277. (b) Schäfer, M.; Mahr, N.; Wolf, J.; Werner, H. Angew. Chem., Int. Ed. Engl. 1993, 32, 1315. (c) Boese, W. T.; Goldman, A. S. Organometallics 1991, 10, 782. (d) Kovalev, I. P.; Yevakov, K. V.; Strelenko, Y. A.; Vinogradov, M. G.; Nikishin, G. I. J. Organomet. Chem. 1990, 386, 139. (e) Schäfer, H.-A.; Marcy, R.; Rüping, T.; Singer, H. J. Organomet. Chem. 1982, 240, 17. (f) Aresta, M.; de Fazio, M. J. Organomet. Chem. 1980, 186, 109. (g) Carlton, L.; Read, G. J. Chem. Soc., Perkin Trans. 1 1978, 1631. (h) Schmitt, H. J.; Singer, H. J. Organomet. Chem. 1978, 153, 165. (i) Yoshikawa, S.; Kiji, J.; Furukawa, J. Makromol. Chem. 1977, 178, 1077. (j) Singer, H.; Wilkinson, G. J. Chem. Soc., A 1968, 849.

(9) (a) Ishikawa, M.; Ohshita, J.; Ito, Y.; Minato, A. J. Chem. Soc. Chem. Commun. 1988, 804. (b) Giacomelli, G.; Marcacci, F.; Caporusso A. M.; Lardicci, L. Tetrahedron Lett. 1979, 3217. (c) Meriwether, L. S.; Colthup, E. C.; Kennerly, G. W.; Reusch, R. N. J. Org. Chem. 1961 26,5155 .

(10) (a) Selimov, F. A.; Rutman, O. G.; Dzhemilev, U. M. J. Organomet. Chem. 1988, 346, C58. (b) Sabourin, E. T. J. Mol. Catal. 1984, 26, 363. (c) Colthup, E. C.; Meriwether, L. S. J. Org. Chem. 1962, 27, 3930. (d) Singer, H.; Wilkinson, G. J. Chem. Soc., A 1968, 190.

(11) (a) Akhtar, M.; Weedon, B. C. L. Proc. Chem. Soc. 1958, 303 (b) Nieuwland, J. A.; Calcott, W. S.; Downing, F. B.; Carter, A. S. J. Am. Chem. Soc. 1931, 53, 4197.

(12) Trost, B. M.; Sorum, M. T.; Chan, C.; Harms, A. E.; Rühter, G. J. Am. Chem. Soc. 1997, 119, 698 . 


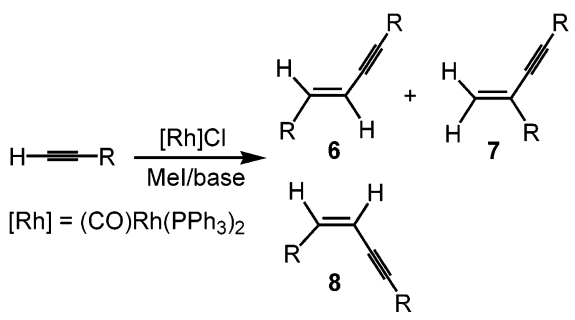

in high yield by using a Pd template. ${ }^{13}$ Bianchini and Peruzzini reported the selective coupling of terminal alkynes to $Z$-1,4-disubstituted butenynes in a catalytic manner by using $\mathrm{Ru}$ complexes. ${ }^{14}$ Another complex, $\mathrm{RuTp}(\mathrm{py})_{2} \mathrm{Cl}(\mathrm{Tp}=$ trispyazolyborate, $\mathrm{py}=$ pyridine $)$, was found to be an efficient catalyst for the selective coupling of $\mathrm{HC} \equiv \mathrm{CPh}$ and allyl alcohol. ${ }^{15}$ The catalytic coupling of $\mathrm{HC} \equiv \mathrm{CR}\left(\mathrm{R}=\mathrm{Ph}, \mathrm{SiMe}_{3}, n-\mathrm{Bu}\right.$, and $t$-Bu) to 1,4- and 2,4-disubstituted butenynes with the aid of $\mathrm{Ru}$ complexes has been reported..$^{16}$ Recently, Miyaura reported the iridium-catalyzed dimerization of terminal alkynes $^{17}$ to give $(E)$-enyne, $(Z)$-enyne, or $1,2,3$-butatriene derivatives in the presence of triethylamine. The reaction used a triarylphosphine complex selectively yielding linear $(E)$-enynes for silylethynes, while the tripropylphosphine complex provided linear $(Z)$-enynes for silylalkynes or 1,2,3-butatrienes for tert-alkylethynes, and formation of a head-to-tail dimer was not observed. Gevorgyan and Rubina discovered that a Pd system in the dimerization of terminal aryl acetylene produced not only the head-to-tail enyne but also a head-to-head $Z$-form enyne. ${ }^{18}$ They synthesized a series of different ortho-substituted aryl alkynes and found that at least one ortho hydrogen in aryl acetylene is involved for a selective head-to-head dimerization reaction. It was proposed that an agostic interaction between the transition metal and ortho proton of the aromatic ring in the substrate is responsible for the observed unusual regioselectivity of the reaction.

Rhodium complexes ${ }^{19}$ have also been used to catalyze the dimerization reaction of terminal alkynes. Rhodium(I) triphenylphosphine complexes are most commonly used as catalysts in these reactions. The selectivity for enyne formation is $65-75 \%$, but alkyne trimerization also takes place. In 1990, Vinogradov and co-workers reported that $\mathrm{RhCl}\left(\mathrm{PMe}_{3}\right)_{3}$ catalyzed dimerization of aliphatic terminal alkynes to form enynes. ${ }^{8 \mathrm{~d}}$ However, the yield of enynes is low and the regio- and stereoselectivity of enynes is poor. For arylalkyne, under this reaction condition no dimer was obtained. 3486 .

13) Trost, B. M.; Chan, C.; Ruhter, G. J. Am. Chem. Soc. 1987, 109,

(14) Guaouzi, M. E.; Yáñez, R.; Ros, J.; Alvarez-Larena, A.; Piniella, J. F. Inorg. Chem. Commun. 1999, 2, 288.

(15) Gemel, C.; Trimmel, G.; Slugovc, C.; Mereiter, K.; Kremel, S.; Schmid, R.; Kirchner, K. Organometallics 1996, 15, 3998.

(16) Slugovc, C.; Mereiter, K.; Zobetz, E.; Schmid, R.; Kirchner, K. Organometallics 1996, 15, 5275.

(17) Ohmura, T.; Yorozuya, S.; Yamamoto, Y.; Miyaura, N. Organometallics 2001, 19, 365 .

(18) Rubina, M.; Gevorgyan, V. J. Am. Chem. Soc. 2001, 123, 11107.

(19) (a) Singer, H.; Wilkinson, G. J. Chem. Soc. (A) 1968, 849. (b) Kern, R. J. J. Chem. Soc., Chem. Commun. 1968, 706. (c) Yoshikawa, S.; Kiji, J.; Furukawa, J. Macromol. Chem. 1977, 178, 1077. (d) Singer, H.; Schmitt, H. J. J. Organomet. Chem. 1978, 153, 165. (e) Carlton, L. Read, G. J. Chem. Soc., Perkin Trans. 1 1978, 1631. (f) Aresta, M.; De Fazio, M. J. Organomet. Chem. 1980, 186, 209. (g) Albano, P.; Aresta, M. J. Organomet. Chem. 1980, 190, 243. (h) Schäfer, H.-A.; Marcy, R.; Rüping, G.; Singer, H. J. Organomet. Chem. 1982, 240, 17.
We are interested in exploring the chemical reactivity of various metal vinylidene complexes ${ }^{20}$ commonly prepared by alkylation ${ }^{21}$ of metal acetylide complexes. However, in the reaction of methyliodide with the rhodium phenylacetylide complex, oxidative addition takes place preferentially followed by a reductive elimination to give the 1-phenyl-1-propyne. Surprisingly a competing dimerization product from the reaction of the terminal acetylide ligand is also observed. This indicates that the intermediate generated in the process could be used to produce a different product. With careful control of the reaction conditions, the system is developed to take advantage of the intermediate formed from the oxidative addition as a catalyst ${ }^{22}$ to catalyze the dimerization of alkynes. Herein, we describe the catalytic enyne formation reaction of terminal arylalkynes at ambient temperature that lead to high conversion and high regio- and stereoselectivity depending on the solvent used.

\section{Results and Discussion}

Stoichiometric Reactions of Rh Acetylide Complexes. The reaction of $\mathrm{HC} \equiv \mathrm{CPh}(\mathbf{1 a})$ with $[\mathrm{Rh}]-\mathrm{Cl}(\mathbf{2}$, $\left.[\mathrm{Rh}]=\mathrm{Rh}(\mathrm{CO})\left(\mathrm{PPh}_{3}\right)_{2}\right)$ in the presence of $\mathrm{MeONa}$ and $\mathrm{CO}$ results in the formation of the rhodium $\sigma$-acetylide complex $[\mathrm{Rh}]-\mathrm{C} \equiv \mathrm{CPh}(\mathbf{3 a})$ in high yield. Complex [Rh]$\mathrm{C} \equiv \mathrm{C}\left(p-\mathrm{C}_{6} \mathrm{H}_{4} \mathrm{NO}_{2}\right)(\mathbf{3 b})$, where the terminal phenyl group on the acetylide ligand is substituted by a $p$-nitrophenyl group, was similarly obtained from $\mathrm{HC} \equiv \mathrm{C}\left(p-\mathrm{C}_{6} \mathrm{H}_{4} \mathrm{NO}_{2}\right)$ (1b) also in high yield. Addition of $\mathrm{MeI}$ to a $\mathrm{CH}_{2} \mathrm{Cl}_{2}$ solution of complex $\mathbf{3 a}$ affords [Rh]-I ( $\left.\mathbf{2}^{\prime}\right)$ and the organic compound $\mathrm{MeC} \equiv \mathrm{CPh}(\mathbf{4 a})$ in quantitative yield. Obviously the reaction proceeds via oxidative addition of $\mathrm{CH}_{3} \mathrm{I}$ leading to an unobserved six-coordinated complex $\mathrm{Rh}(\mathrm{CO})\left(\mathrm{PPh}_{3}\right)_{2}(\mathrm{Me}) \mathrm{I}(\mathrm{C} \equiv \mathrm{CPh})$ followed by reductive elimination to give $[\mathrm{Rh}]-\mathrm{I}\left(\boldsymbol{2}^{\prime}\right)$ and $\mathbf{4 a}$. Alkylation at $\mathrm{C}_{\beta}$ of the acetylide ligand leading to the vinylidene complex was not observed.

Interestingly, when $\mathrm{ICH}_{2} \mathrm{CN}$ is used to react with $\mathbf{3 a}$, the six-coordinated complex $\mathrm{Rh}(\mathrm{CO})\left(\mathrm{PPh}_{3}\right)_{2}\left(\mathrm{CH}_{2} \mathrm{CN}\right) \mathrm{I}$ $(\mathrm{C} \equiv \mathrm{CPh})(\mathbf{5 a})$ is obtained in high yield. Namely, the reductive elimination reaction is obstructed by the presence of the electron-withdrawing $\mathrm{CN}$ group even at

(20) (a) Ting, P. C.; Lin, Y. C.; Cheng, M. C.; Wang, Y. Organometallics 1994, 13, 2150. (b) Lo, Y. H.; Lin, Y. C.; Lee, G. H.; Wang, Y. Organometallics 1999, 18, 982. (c) Chang, C. W.; Lin, Y. C.; Lee, G. H.; Wang, Y. Organometallics 2000, 19, 3211. (d) Lin, Y. C. J. Organomet. Chem. 2001, 617-618, 141. (e) Liu, J. F.; Huang, S. L.; Lin, Y. C.; Liu, Y. H.; Wang, Y. Organometallics 2002, 21, 1355. (f) Huang, C. C.; Lin, Y. C.; Huang, S. L.; Liu, Y. H.; Wang, Y. Organometallics 2003, 22, 1512.

(21) (a) Bruce, M. I. Chem. Rev. 1991, 91, 197. (b) Gamasa, M. P. Gimeno, J.; Martin-Vaca, B.; Borge, J.; Garcia-Granda, S.; PerezCarrenõ, E. Organometallics 1994, 13, 4045. (c) Bianchini, C.; Glendenning, L.; Peruzzini, M.; Romerosa, A.; Zanobini, F. J. Chem. Soc., Chem. Commun. 1994, 2219. (d) Werner, H. J. Organomet. Chem. 1994, 475, 45. (e) Ting, P.-C.; Lin, Y.-C.; Lee, G.-H.; Cheng, M.-C.; Wang, Y. J. Am. Chem. Soc. 1996, 118, 6433. (f) Bernad, D. J.; Esteruelas, M. A.; López, A. M.; Modrego, J.; Puerta, M. C.; Valerga, P. Organometallics 1999, 18, 4995. (g) Bruneau, C.; Dixneuf, P. H. Acc. Chem. Res. 1999, 32, 311. (h) Fürstner, A. Chem. Rev. 2000, 100, 3012. (i) Baya, M.; Crochet, P.; Esteruelas, M. A.; Gutierrez-Puebla, E.; López, A. M.; Modrego, J.; Onate, E.; Vela, N. Organometallics 2000, 19, 2585 (j) Louise, J.; Grubbs, R. H. Angew. Chem., Int. Ed. 2001, 40, 247, and references therein. (k) Trost, B. M.;. Toste, F. D.; Pinkerton, A. B. Chem. Rev. 2001, 101, 2067. (1) Alvarez, P.; Lastra, E.; Gimeno, J.; Bassetti, M.; Falvello, L. R. J. Am. Chem. Soc. 2003, 125, 2386.

(22) (a) Jang, H.-Y.; Huddleston, R. R.; Krische, M. J. J. Am. Chem Soc. 2004, 126, 4664. (b) Jang, H.-Y.: Krische, M. J. Acc. Chem. Res. 2004, 37, 653 . 


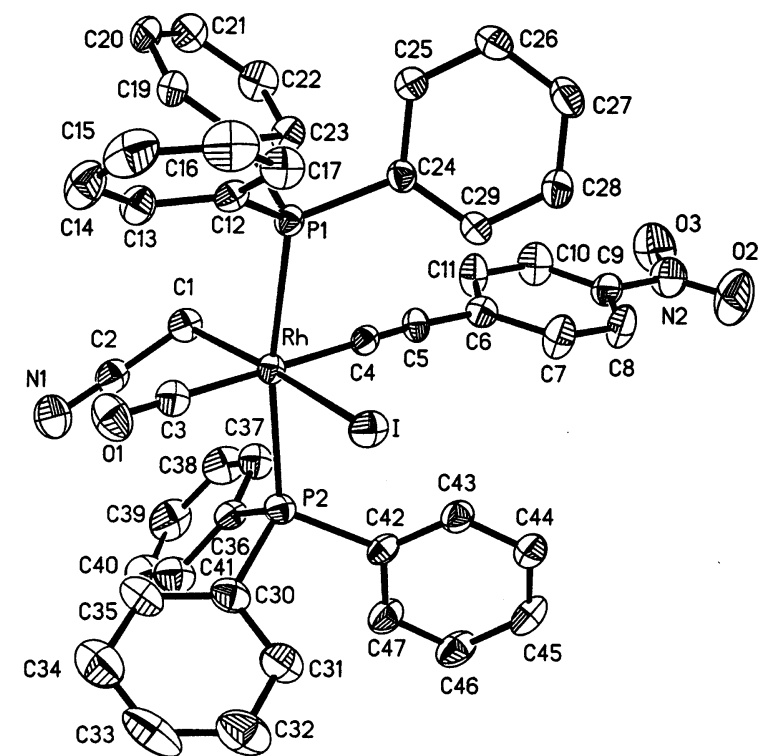

Figure 1. ORTEP drawing of $\mathbf{5 b}$.

Table 1. Selected Bond Lengths $(\AA)$ and Bond Angles (deg) of 5b

\begin{tabular}{lcll}
\hline $\mathrm{Rh}-\mathrm{I}$ & $2.7923(10)$ & $\mathrm{Rh}-\mathrm{P} 1$ & $2.3912(23)$ \\
$\mathrm{Rh}-\mathrm{P} 2$ & $2.3953(24)$ & $\mathrm{Rh}-\mathrm{C} 1$ & $2.146(8)$ \\
$\mathrm{Rh}-\mathrm{C} 3$ & $1.919(9)$ & $\mathrm{Rh}-\mathrm{C} 4$ & $2.010(8)$ \\
$\mathrm{C} 1-\mathrm{C} 2$ & $1.428(12)$ & $\mathrm{C} 2-\mathrm{N} 1$ & $1.143(12)$ \\
$\mathrm{C} 3-\mathrm{O} 1$ & $1.121 .(10)$ & $\mathrm{C} 4-\mathrm{C} 5$ & $1.189(11)$ \\
& & & \\
$\mathrm{I}-\mathrm{Rh}-\mathrm{C} 1$ & $170.36(24)$ & $\mathrm{I}-\mathrm{Rh}-\mathrm{C} 3$ & $80.65(25)$ \\
$\mathrm{I}-\mathrm{Rh}-\mathrm{C} 4$ & $101.56(22)$ & $\mathrm{I}-\mathrm{Rh}-\mathrm{P} 1$ & $87.77(6)$ \\
$\mathrm{I}-\mathrm{Rh}-\mathrm{P} 2$ & $89.55(6)$ & $\mathrm{Rh}-\mathrm{C} 1-\mathrm{C} 2$ & $112.3(6)$ \\
$\mathrm{Rh}-\mathrm{C} 3-\mathrm{O} 1$ & $178.6(7)$ & $\mathrm{Rh}-\mathrm{C} 4-\mathrm{C} 5$ & $178.3(7)$ \\
$\mathrm{C} 1-\mathrm{C} 2-\mathrm{N} 1$ & $177.3(10)$ & $\mathrm{C} 4-\mathrm{C} 5-\mathrm{C} 6$ & $172.1(9)$
\end{tabular}

$60{ }^{\circ} \mathrm{C}$. Complex $\mathrm{Rh}(\mathrm{CO})\left(\mathrm{PPh}_{3}\right)_{2}\left(\mathrm{CH}_{2} \mathrm{CN}\right) \mathrm{I}\left(\mathrm{C} \equiv \mathrm{C}\left(p-\mathrm{C}_{6} \mathrm{H}_{4}-\right.\right.$ $\left.\mathrm{NO}_{2}\right)$ (5) tuted by a $p$-nitrophenyl group, is similarly prepared from $\mathbf{3 b}$ and fully characterized by an X-ray diffraction analysis. An ORTEP drawing of $\mathbf{5 b}$ is shown in Figure 1 , and selected bond lengths and angles are collected in Table 1 . The coordination sphere of the $\mathrm{Rh}$ center can be described as octahedral with the cyanomethyl and the acetylide ligands in cis disposition and the cyanomethyl and iodide ligands in trans disposition. This kind of cis disposition should also be present in the reaction of $\mathbf{3 a}$ with $\mathrm{MeI}$; it is therefore not surprising to see rapid formation of $\mathbf{4 a}$ via reductive elimination. Alkylation reaction of terminal acetylenes $\mathbf{1 a}$ and $\mathbf{1 b}$ with $\mathrm{MeI}$ in $\mathrm{MeOH}$ could be carried out catalytically in the presence of $\mathbf{2}^{\prime}$ and the base $\mathrm{MeONa}$ at room temperature. The product $\mathbf{4 a}$ is isolated in $88 \%$ yield in $6 \mathrm{~h}$ and $\mathrm{MeC} \equiv \mathrm{C}\left(p-\mathrm{C}_{6} \mathrm{H}_{4} \mathrm{NO}_{2}\right)(\mathbf{4 b})$ in $95 \%$ yield in $1 \mathrm{~h}$.

Catalytic Dimerization of Alkyne. When the abovementioned procedure was extended to the reaction of rhodium complexes with other terminal aryl alkynes, we observed dimerization of alkyne. From the aryl alkyne $\mathrm{HC} \equiv \mathrm{C}\left(p-\mathrm{C}_{6} \mathrm{H}_{4} \mathrm{CHO}\right)$ (1c), in addition to the desired alkylation product $\mathbf{4 c}$, the (E)-1,4-disubstituted enyne 6c (see Scheme 1) was also obtained in high yield. The stoichiometric reaction of $\mathbf{2}$ with $\mathbf{1 c}$ was first carried out in the presence of $\mathrm{MeI}$ and $\mathrm{K}_{2} \mathrm{CO}_{3}$ in $\mathrm{MeOH}$ at room temperature. After $5 \mathrm{~h}$, the ${ }^{1} \mathrm{H}$ NMR spectrum of the crude reaction mixture revealed the formation of the alkylation product $4 \mathbf{c}$ in low yield possibly due to the reactive aldehyde group in $1 \mathrm{c}$ in the presence of $\mathrm{K}_{2} \mathrm{CO}_{3}$

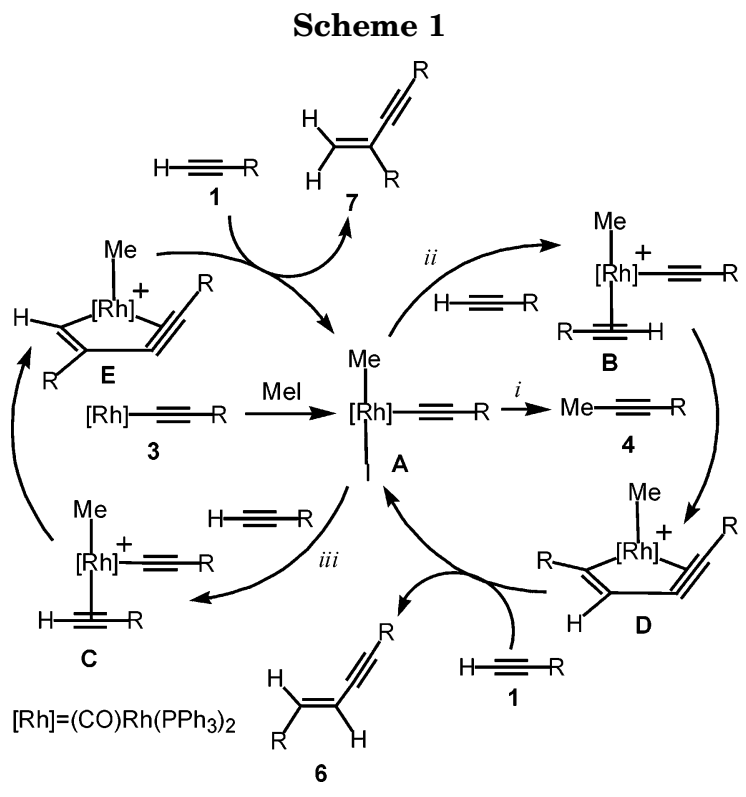

Table 2. Effect of the Solvent on Rhodium-Catalyzed Dimerization of $1 a^{a}$

\begin{tabular}{|c|c|c|c|c|c|c|c|}
\hline entry & solvent & $\underset{(\mathrm{mol}}{\mathbf{2}}$ & $\underset{\text { (equiv) }}{\text { MeI }}$ & $\begin{array}{l}\text { ratio for } \\
\mathbf{6 a}: 7 \mathbf{a}: 4 \mathbf{a}\end{array}$ & $\underset{(\mathrm{h})}{\operatorname{time}}$ & $\begin{array}{c}\text { conversion } \\
(\%)\end{array}$ & $\begin{array}{c}\text { yield } \\
(\%) \\
\text { for } \mathbf{6 a}\end{array}$ \\
\hline 1 & $\mathrm{MeOH}$ & 5 & 2 & $0: 0: 100$ & 2 & 100 & $0^{c}$ \\
\hline 2 & $\mathrm{THF}$ & 5 & 3 & $78: 19: 3$ & 24 & 100 & $70^{c}$ \\
\hline 3 & $\mathrm{CH}_{2} \mathrm{Cl}_{2}$ & 1 & 0.5 & $81: 18: 1$ & 18 & 100 & $75^{c}$ \\
\hline 4 & benzene & 5 & 3 & $79: 20: 1$ & 18 & 100 & $71^{c}$ \\
\hline 5 & ether & 5 & 1 & $71: 19: 10$ & 18 & 47 & $33^{b}$ \\
\hline 6 & acetone & 5 & 3 & $79: 20: 1$ & 18 & 100 & $70^{c}$ \\
\hline 7 & $\mathrm{MeCN}$ & 5 & 1 & $5: 5: 90$ & 18 & 100 & $5^{b}$ \\
\hline
\end{tabular}

${ }^{a}$ Catalyst: $\left[\mathrm{Rh}(\mathrm{CO})\left(\mathrm{PPh}_{3}\right)_{2} \mathrm{Cl}\right] / \mathrm{K}_{2} \mathrm{CO}_{3}$ (10 equiv). ${ }^{b} \mathrm{NMR}$ yield. ${ }^{c}$ Isolated yield.

in $\mathrm{MeOH}$. We modified the catalytic reaction by using THF. Interestingly, the reaction of $1 \mathbf{c}$ with $\mathrm{MeI}$ in the presence of 2 and $\mathrm{K}_{2} \mathrm{CO}_{3} / \mathrm{THF}$ at room temperature for $24 \mathrm{~h}$ afforded $4 \mathbf{c}$ and the dimerization product $6 \mathbf{c}$ in a 1:2 ratio, which could be separated by chromatography, and $6 \mathbf{c}$ was identified by ${ }^{1} \mathrm{H}$ and ${ }^{13} \mathrm{C}$ NMR and EI mass spectrum. The ${ }^{1} \mathrm{H}$ NMR spectrum of $\mathbf{6 c}$ displays two doublet signals at $\delta 7.14$ and 6.55 with ${ }^{3} J_{\mathrm{H}-\mathrm{H}}=16.2$ $\mathrm{Hz}$, indicating the presence of two trans olefinic protons. Two singlet signals at $\delta 9.99$ and 9.98 are assigned to two aldehyde protons. In the ${ }^{13} \mathrm{C}$ NMR spectrum of $\mathbf{6 c}$, two singlet resonances at $\delta 191.43$ and 191.33 are assigned to two carbonyl carbons. The ${ }^{13} \mathrm{C}$ signals of the $\mathrm{C}=\mathrm{C}$ group appear at $\delta 114.6$ and 111.1.

$(E)$-1,4-Disubstituted Enynes from Terminal Alkynes. In our optimization studies, phenyl-acetylene was used as the model substrate for the dimerization. The catalytic system consists of $5 \mathrm{~mol} \%$ of 2 and 3 equiv of MeI with 10 equiv of $\mathrm{K}_{2} \mathrm{CO}_{3}$ as a base in THF. Most reactions were complete in $18 \mathrm{~h}$. The ratio of $(E)-1,4-$ disubstituted enyne $\mathbf{6 a}, 1,3$-disubstituted enyne $\mathbf{7 a}$, and the alkylation product $\mathbf{4 a}$ is 78:19:3 from the reaction of 1a, showing good chemo-, regio-, and stereoselectivity. The head-to-head dimeric product ( $Z$ )-1,4-disubstituted enyne was not obtained. The structure of $\mathbf{6 a}$ was readily determined by the coupling constant between two olefinic protons $(J=16.2 \mathrm{~Hz})$ for the $(E)$-enyne as compared to that $(J=11.9 \mathrm{~Hz})$ of the $(Z)$-enyne. Table 2 lists our survey of various solvents for this system showing nearly complete dimerization and similar 
Table 3. Dimerization of Terminal Alkynes to Enynes Catalyzed by the $\left[\mathrm{Rh}(\mathrm{CO})\left(\mathrm{PPh}_{3}\right)_{2} \mathrm{Cl}\right] / \mathrm{K}_{2} \mathrm{CO}_{3} / \mathrm{MeI}$ System $^{a}$

\begin{tabular}{|c|c|c|c|c|c|c|c|}
\hline entry & $\mathrm{R}$ & $2(\operatorname{mol} \%)$ & $\begin{array}{c}\text { MeI } \\
\text { (equiv) }\end{array}$ & $\begin{array}{c}\text { ratio for } \\
6: 7: 4\end{array}$ & $\begin{array}{c}\text { time } \\
(\mathrm{h})\end{array}$ & $\begin{array}{c}\text { conversion } \\
(\%)\end{array}$ & $\begin{array}{l}\text { yield }(\%) \\
\text { for } 6\end{array}$ \\
\hline $1^{e}$ & 1a, $\mathrm{Ph}$ & 1 & 0.5 & 81:18:1 & 18 & 100 & $75^{c}$ \\
\hline 2 & $\mathbf{1 b}, p-\mathrm{C}_{6} \mathrm{H}_{4} \mathrm{NO}_{2}$ & 5 & 3 & $60: 15: 25$ & 48 & 100 & $52^{c}$ \\
\hline 3 & 1c, $p-\mathrm{C}_{6} \mathrm{H}_{4} \mathrm{CHO}$ & 5 & 3 & 67:0:33 & 4 & 100 & $60^{c}$ \\
\hline $4^{d}$ & 1d, $p-\mathrm{C}_{6} \mathrm{H}_{4} \mathrm{Me}$ & 5 & 3 & $92: 0: 8$ & 48 & 100 & $90^{c}$ \\
\hline 5 & $\mathbf{1 e}, p-\mathrm{C}_{6} \mathrm{H}_{4} \mathrm{CN}$ & 1 & 0.1 & $83: 3: 14$ & 48 & 84 & $54^{c} ; 69^{b}$ \\
\hline $6^{d}$ & 1f, $p-\mathrm{C}_{6} \mathrm{H}_{4} \mathrm{NMe}_{2}$ & 1 & 0.1 & $90: 8: 2$ & 40 & 100 & $82^{c}$ \\
\hline 7 & $\mathbf{1 g}, p-\mathrm{C}_{6} \mathrm{H}_{4} \mathrm{CF}_{3}$ & 5 & 3 & $97: 0: 3$ & 24 & 100 & $90^{c}$ \\
\hline $8^{e}$ & 1h, $p-\mathrm{C}_{6} \mathrm{H}_{4} \mathrm{~F}$ & 5 & 3 & & 24 & & $39^{c}$ \\
\hline $9^{e}$ & 1i, $p-\mathrm{C}_{6} \mathrm{H}_{4} \mathrm{Br}$ & 1.25 & 0.25 & $93: 3: 4$ & 24 & 98 & $88^{c}$ \\
\hline $10^{e}$ & $\mathbf{1 j}, p-\mathrm{C}_{6} \mathrm{H}_{4} \mathrm{I}$ & 1 & 0.1 & & 14 & 100 & $77^{c}$ \\
\hline 11 & $\mathbf{1 k}, n-\mathrm{Bu}$ & 5 & 3 & 10:90:0 & 18 & 100 & $f$ \\
\hline
\end{tabular}

${ }^{a}$ Catalyst: $\left[\mathrm{Rh}(\mathrm{CO})\left(\mathrm{PPh}_{3}\right)_{2} \mathrm{Cl}\right](\mathbf{2}) / \mathrm{K}_{2} \mathrm{CO}_{3}(10$ equiv $) / \mathrm{THF}(10 \mathrm{~mL}) .{ }^{b} \mathrm{NMR}$ yield. ${ }^{c}$ Isolated yield. ${ }^{d} 5$ equiv of NaOMe as base. ${ }^{e} 5 \mathrm{~mL}$ of $\mathrm{CH}_{2} \mathrm{Cl}_{2}$ as solvent. $f$ 7k in $72 \%$ isolated yield.

Table 4. Dimerization of Terminal Alkynes to $(\mathrm{Z})$-Enynes Catalyzed by the $\left[\mathrm{Rh}(\mathrm{CO})\left(\mathrm{PPh}_{3}\right)_{2} \mathrm{Cl}_{3} / \mathrm{K}_{2} \mathrm{CO}_{3} / \mathrm{CH}_{3} \mathrm{I}\right.$ System in $\mathrm{MeOH}^{a}$

\begin{tabular}{|c|c|c|c|c|c|c|c|}
\hline entry & $\mathrm{R}$ & $\begin{array}{c}\mathbf{2} \\
(\mathrm{mol} \%)\end{array}$ & $\begin{array}{c}\text { MeI } \\
\text { (equiv) }\end{array}$ & $\begin{array}{c}\text { ratio for } \\
\mathbf{6 : 8 : 4}\end{array}$ & $\underset{(\mathrm{h})}{\operatorname{time}}$ & $\begin{array}{c}\text { conversion } \\
(\%)\end{array}$ & $\begin{array}{l}\text { yield }(\%) \\
\text { for } 8\end{array}$ \\
\hline 1 & 1a, $\mathrm{Ph}$ & 1 & 0.1 & $13: 82: 5$ & 16 & 100 & $82^{b}, 63^{c}$ \\
\hline $2^{e}$ & $\mathbf{1 b}, p-\mathrm{C}_{6} \mathrm{H}_{4} \mathrm{NO}_{2}$ & 1 & 0.1 & & 18 & & \\
\hline $3^{e}$ & 1c, $p-\mathrm{C}_{6} \mathrm{H}_{4} \mathrm{CHO}$ & 1 & 0.1 & & 18 & & \\
\hline $4^{d, e}$ & 1d, $p-\mathrm{C}_{6} \mathrm{H}_{4} \mathrm{Me}$ & 1 & 0.1 & & 48 & & \\
\hline 5 & 1e, $p-\mathrm{C}_{6} \mathrm{H}_{4} \mathrm{CN}$ & 1 & 0.1 & $0: 95: 5$ & 48 & 96 & $82^{c}$ \\
\hline $6^{d, e}$ & 1f, $p-\mathrm{C}_{6} \mathrm{H}_{4} \mathrm{NMe}_{2}$ & 1 & 0.1 & & 40 & & \\
\hline 7 & $1 \mathrm{~g}, p-\mathrm{C}_{6} \mathrm{H}_{4} \mathrm{CF}_{3}$ & 1 & 0.1 & 0:99.5:0.5 & 18 & 100 & $91^{c}$ \\
\hline 8 & 1h,$p-\mathrm{C}_{6} \mathrm{H}_{4} \mathrm{~F}$ & 1 & 0.1 & & 18 & & $25^{c}$ \\
\hline 9 & 1i, $p-\mathrm{C}_{6} \mathrm{H}_{4} \mathrm{Br}$ & 1 & 0.1 & $0: 97: 3$ & 18 & 100 & $90^{c}$ \\
\hline 10 & $\mathbf{1 j}, p-\mathrm{C}_{6} \mathrm{H}_{4} \mathrm{I}$ & 1 & 0.1 & $0: 80: 20$ & 14 & 57 & $35^{c}$ \\
\hline
\end{tabular}

${ }^{a}$ Catalyst: $\left[\mathrm{Rh}(\mathrm{CO})\left(\mathrm{PPh}_{3}\right)_{2} \mathrm{Cl}\right](\mathbf{1 a}) / \mathrm{K}_{2} \mathrm{CO}_{3}\left(10\right.$ equiv)/MeOH $(5 \mathrm{~mL}) .{ }^{b} \mathrm{NMR}$ yield. ${ }^{c}$ Isolated yield. ${ }^{d} 5$ equiv of $\mathrm{MeONa}$ as base. ${ }^{e}(Z)-$ Enynes were not observed.

product distribution in some aprotic solvents. Dimerization reaction of phenylacetylene was not observed in $\mathrm{MeOH}$, as shown in entry 1 . Low conversion in entry 5 could be due to the low solubility of rhodium complex 2 in ether. Acetonitrile appears to be an inappropriate solvent in the dimerization of phenylacetylene, presumably because of its coordinating nature (entry 7). Furthermore, as shown in Table 3, a survey of various terminal arylacetylenes for this system shows nearly complete dimerization and similar product distribution in a variety of solvents such as THF and $\mathrm{CH}_{2} \mathrm{Cl}_{2}$. All $E$-form enyne products 6 are characterized by ${ }^{1} \mathrm{H}$ and ${ }^{13} \mathrm{C}$ NMR and FAB mass spectroscopic data.

For the catalytic dimerization reaction of arylalkyne with electron-donating groups such as $\mathrm{CH}_{3}$ (1d) and $\mathrm{NMe}_{2}$ (1f) on the aryl ring, a stronger base such as $\mathrm{MeONa}$ is required (entries 4,6 ). Substrate $\mathbf{1 h}$ suffers from low yield (entry 8). For dimerization of $\mathbf{1} \mathbf{j}$, because of the low solubility of $\mathbf{6 j}$, the crude dimeric product ratio was not determined by ${ }^{1} \mathrm{H}$ NMR (entry 10 ). For alkyne $1 \mathbf{c}\left(\mathrm{R}=p-\mathrm{C}_{6} \mathrm{H}_{4} \mathrm{CHO}\right)$, the (E)-enyne $6 \mathbf{c}$ and alkylation product $4 \mathbf{c}$ are formed in a ratio of $67: 33 \%(\mathbf{6 c : 4 c})$ with $100 \%$ conversion (entry 3 ). Finally, the aliphatic alkyne $\mathbf{1 k}$ produces corresponding head-to-tail dimer $\mathbf{7 k}$ as the major product (entry 11). Dimerization of $\mathbf{1 h}, \mathbf{1 i}, \mathbf{1} \mathbf{j}$, and 1c to form enynyl products was not reported previously. This may be due to high affinity of the $\mathrm{C}-\mathrm{X}$ bond of the aryl halide to the Pd catalyst.

(Z)-1,4-Disubstituted Enynes from Terminal Alkynes. The rhodium-catalyzed dimerization reaction of terminal alkynes in aprotic solvents such as THF, $\mathrm{CH}_{2} \mathrm{Cl}_{2}$, acetone, and benzene gives $(E)$-1,4-disubstituted enynes, but the corresponding $Z$-form isomer of 1,4- disubstituted enynes was not obtained. When $\mathrm{MeOH}$ is used, dimerization reactions of 1-alkynes catalyzed by 2 afforded (Z)-1,4-disubstituted enynes 8 at room temperature in excellent yield with high chemo-, regio-, and stereoselectivity. The catalytic system consisting of 1 mol \% of 2 and 0.1 equiv of $\mathrm{MeI}$ with 10 equiv of $\mathrm{K}_{2} \mathrm{CO}_{3}$ as a base was tested in $\mathrm{MeOH}$ for the catalytic activity of the dimerization of various 1-alkynes (see Table 4). For the dimerization of $\mathbf{1 a}(\mathrm{R}=\mathrm{Ph})$, the reaction was complete in $16 \mathrm{~h}$. The product ratio of $(E)$-1,4-disubstituted enyne $\mathbf{6 a},(Z)$-1,4-disubstituted enyne $\mathbf{8 a}$, and the alkylation product 4a is 13:82:5 (entry 1 ). The head-totail dimeric product 1,3-disubstituted enyne $\mathbf{7 a}$ was not obtained. The structure of the $(Z)$-enyne was readily determined by the coupling constant between two olefinic cis-protons $(J=11.9 \mathrm{~Hz})$. A number of other terminal arylacetylenes undergo nearly complete dimerization and give a similar product distribution in $\mathrm{MeOH}$ (Table 4). For the dimerization of $\mathrm{HC} \equiv \mathrm{C}\left(p-\mathrm{C}_{6} \mathrm{H}_{4} \mathrm{CN}\right)$ (1e), the reaction was complete in $48 \mathrm{~h}$. The product ratio of 8e:4e is 95:5 (entry 3). For $\mathbf{1 g}$, high conversion (100\%) and excellent selectivity (99.5\% in $Z$-isomer) are found for the catalytic dimerization reaction (entry 7 ). Dimerization of $1 \mathbf{i}$ reveals similar selectivity and conversion (entry 9$)$. In the case of $\mathbf{1 j}\left(\mathrm{R}=4-\mathrm{C}_{6} \mathrm{H}_{4} \mathrm{I}\right)$, the dimerization reaction results in lower selectivity and lower conversion (57\%) (entry 10).

However, in cases of dimerization reaction of 1-arylalkynes, bearing $\mathrm{Me}_{2} \mathrm{~N}, \mathrm{NO}_{2}$, and $\mathrm{Me}$ groups at the paraposition of the aryl group, neither $(E)$-enynes nor $(Z)$ enynes were obtained (Table 4 ). The reaction of $\mathbf{1 b}$ with $\mathrm{MeI}$ in the presence of $\mathbf{2}$ and $\mathrm{K}_{2} \mathrm{CO}_{3}$ in $\mathrm{MeOH}$ afforded only the alkylation product $\mathbf{4 b}$ in $10 \%$ NMR yield (entry 
$2)$. No dimeric $(E)$ - or $(Z)$-enyne was obtained. This is clearly due to the presence of a para- $\mathrm{NO}_{2}$ group at the phenyl group of $\mathbf{1 b}$. For $\mathrm{HC} \equiv \mathrm{C}\left(p-\mathrm{C}_{6} \mathrm{H}_{4} \mathrm{Me}\right)(\mathbf{1 d})$, no $Z$-form enyne was observed in $\mathrm{MeOH}$. Under catalytic conditions, the reaction of $\mathbf{1 d}$ with $\mathrm{MeI}$ in $\mathrm{MeOH}$ affords the alkylation product $\mathbf{4 d}, \mathbf{3 d}$, and a trace amount of the $E$-form enyne 6d (entry 4). For 1f, only the alkylation product $\mathbf{4 f}$ was obtained (entry 6 ). In the dimerization reaction of $\mathbf{1 h}$ in $\mathrm{MeOH}$ the low yield of $(Z)$ enyne $8 \mathbf{h}$ could be due to an unstable reaction intermediate (entry 8). Finally, the reaction of alkyne 1c under catalytic conditions in $\mathrm{MeOH}$ affords a black, insoluble solid, which was not characterized (entry 3). We proposed that the black solid is derived from polymerization of $\mathbf{1 c}$ in the presence of $\mathbf{2}$ and $\mathrm{K}_{2} \mathrm{CO}_{3} / \mathrm{MeOH} .{ }^{21}$ To the best of our knowledge, the transition metal-catalyzed dimerization of 1-arylalkyne with high regioselectivity to the head-to-head $(Z)$-enynes is rare.

In 1991, Bianchini and co-workers reported that the selective coupling of terminal alkynes to $Z$-1,4-disubstituted butenynes can be achieved catalytically by using either the Ru hydrido complex $\left[\left(\mathrm{PP}_{3}\right) \mathrm{Ru}(\mathrm{H})\left(\eta^{2}-\mathrm{H}_{2}\right)\right]-$ $\mathrm{BPh}_{4}$ or the $\eta^{1}$-dinitrogen derivative $\left[\left(\mathrm{PP}_{3}\right) \mathrm{Ru}(\mathrm{H})\left(\mathrm{N}_{2}\right)\right]$ $\mathrm{BPh}_{4}\left(\mathrm{PP}_{3}=\mathrm{P}\left(\mathrm{CH}_{2} \mathrm{CH}_{2} \mathrm{PPh}_{2}\right)_{3}\right){ }^{7 \mathrm{~b}}$ When complex $\left[\left(\mathrm{PP}_{3}\right)-\right.$ $\left.\mathrm{Ru}\left(\mathrm{C} \equiv \mathrm{CSiMe}_{3}\right)\right] \mathrm{BPh}_{4}$ is reacted with excess $\mathrm{HC} \equiv \mathrm{CSiMe}_{3}$, catalytic production of $(Z)$-1,4-bis(trimethylsilyl)but-3en-1-yne was observed.

Proposed Mechanism of Rhodium-Catalyzed Dimerization. There were only a few mechanistic studies on $\mathrm{Rh}(\mathrm{I})$ - and $\mathrm{Pd}(\mathrm{I})$-catalyzed terminal alkyne dimerization reactions that provided direct evidence. It is generally accepted that the first step is the addition of the terminal alkyne to the transition metal catalyst to yield a metal acetylide complex intermediate $(\mathrm{M}=$ $\mathrm{Rh}, \mathrm{Pd}) .{ }^{13,18,21,23}$ Indeed, the reaction of 1-alkynes with 2 in the presence of base results in formation of $\mathrm{Rh}(\mathrm{I})$ acetylide complexes. Further reaction of $\mathrm{Rh}(\mathrm{I})$-acetylide complex with alkyl halide affords a six-coordinated $\mathrm{Rh}$ (III) complex by oxidative addition. In the absence of MeI, the reaction of alkyne $\mathbf{1}$ with $\mathbf{2}$ and a base affords only the Rh-acetylide complex. Thererore, formation of the metal acetylide should be derived from the reaction of rhodium chloride with the deprotonated terminal alkyne by base, instead of a direct oxidative addition. In the absence of a base, there is no reaction of the mixture of alkyne $\mathbf{1}$ and $\mathbf{2}$ in $\mathrm{MeOH}$, THF, or $\mathrm{CH}_{2} \mathrm{Cl}_{2}$. The dimerization reaction of $1 \mathbf{c}$ with $5 \mathrm{~mol} \%$ of the $\mathrm{Rh}(\mathrm{III})$ complex $\mathrm{Rh}(\mathrm{CO})\left(\mathrm{PPh}_{3}\right)_{2}(\mathrm{Cl}) \mathrm{I}_{2}$, prepared by iodination of $\mathbf{2}$, under catalytic conditions at room temperature affords the $E$-form disubstituted enyne $\mathbf{6 c}$ in low yield due to poor catalytic activity of $\mathrm{Rh}(\mathrm{CO})\left(\mathrm{PPh}_{3}\right)_{2}$ $(\mathrm{Cl}) \mathrm{I}_{2}$.

On the basis of these observations, the proposed mechanism is depicted in the Schemes 1 and 2. The sixcoordinated methyl acetylide $\mathrm{Rh}(\mathrm{III})$ complex (CO)Rh$\left(\mathrm{PPh}_{3}\right)_{2}(\mathrm{C} \equiv \mathrm{CR})(\mathrm{Me})(\mathrm{I}) \quad(\mathbf{A})$ is considered as the key intermediate. The catalytic cycle is initiated with formation of $\mathbf{A}$ from oxidative addition of $\mathrm{MeI}$ to $\mathbf{3}$. Then coordination of the second terminal alkyne to the $\mathrm{Rh}$ atom affords two rhodium complexes, $\mathbf{B}$ and $\mathbf{C}$, via two

(23) (a) Stang, P. J ; Crittell, C. M. Organometallics 1990, 9, 3191. (b) Huang, L. Y.; Aulwurm, U. R.; Heinemann, F. W.; Kisch, H. Eur. J. Inorg. Chem. 1998, 1951. (c) Field, L. D.; Ward, A. J.; Turner, P. Aust. J. Chem. 1999, 52, 1085. (d) Fairlamb, I. J. S.; Bäuerlein, P. S.; Marrison, L. R. Dickinson, J. M. Chem. Commun. 2003, 632.

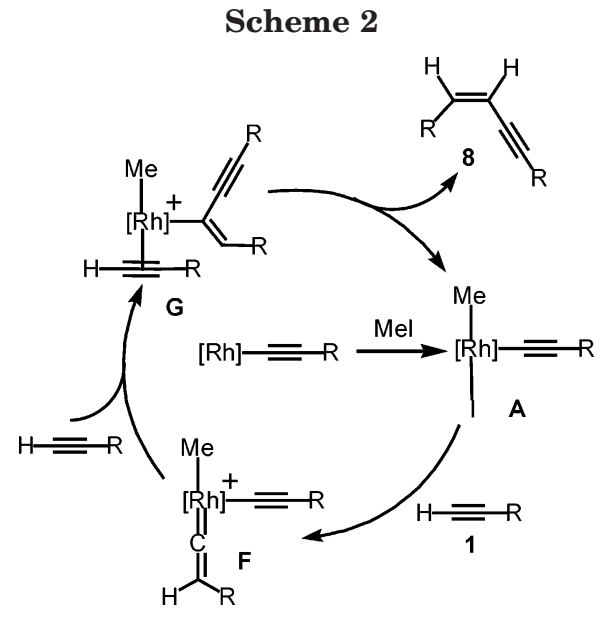

pathways, $i i$ and iii, respectively. ${ }^{24}$ Complex A could also undergo reductive elimination, affording the alkylation product $\mathrm{MeC} \equiv \mathrm{CR}, \mathbf{4}$, via pathway $i$. To hamper the reductive elimination pathway, the amount of MeI was reduced. The reaction favored pathway $i i$ for the alkyne substrate bearing an aryl group. In this pathway, a second terminal alkyne coordinates to the $\mathrm{Rh}$ atom, leading to the butenynyl intermediate $\mathbf{D}$. Then further reaction of $\mathbf{D}$ with alkyne affords the product $E$-enynes 6, regenerating A. However, for aliphatic alkyne such as 1-hexyne, the head-to-tail dimer $\mathbf{7}$ is formed more favorably than the head-to-head $E$-isomer 6 in the enyne formation reaction. The reaction may thus proceed through pathway iii.

Recently, Kirchner and co-workers reported that a $\mathrm{TpRu}$ acetylide complex reacts readily with stoichiometric amounts of $\mathrm{HC} \equiv \mathrm{CPh}$ in benzene to give the alkyne coupling product featuring an $(E)$-1,4-enynyl ligand. ${ }^{25}$ Head-to-head coupling with $E$ - or $Z$-selectivity is, however, more frequently reported. In 1997, Jordan and Yoshida reported that the dicarbollide methyl complex $\left(\mathrm{Cp}^{*}\right)\left(\eta^{5}-\mathrm{C}_{2} \mathrm{~B}_{9} \mathrm{H}_{11}\right) \mathrm{Hf}\left(\mu-\eta^{2}: \eta^{3}-\mathrm{C}_{2} \mathrm{~B}_{9} \mathrm{H}_{11}\right) \mathrm{Hf}\left(\mathrm{Cp}^{*}\right)$ $\mathrm{Me}_{2}\left(\mathrm{Cp}^{*}=\mathrm{C}_{5} \mathrm{Me}_{5}\right)$ catalyzed the regioselective dimerization of terminal alkynes $\mathrm{HC} \equiv \mathrm{CR}\left(\mathrm{R}=\mathrm{Me},{ }^{n} \mathrm{Pr},{ }^{t} \mathrm{Bu}\right)$ to 2,4-disubstituted 1-buten-3-ynes. ${ }^{26}$

In $\mathrm{MeOH}$ the reaction of 1-alkyne with an equal amount of MeI in the presence of $1-5 \mathrm{~mol} \%$ of catalyst 2 and base results in alkylation product $\mathrm{MeC} \equiv \mathrm{CR}$ (4). However, when the amount of MeI was reduced, the reaction leads to formation of the $(Z)$-1,4-disubstituted enyne 8 in $\mathrm{MeOH}$. The proposed mechanism for the formation of enyne $\mathbf{8}$ is shown in Scheme 2 (pathway $i v .^{27}$ On the basis of the fact that a small amount of alkylation product 4 was always obtained in most enyne formation reactions, we propose that the six-coordinated complex $\mathbf{A}$ is also the intermediate in the dimerization

(24) (a) Windmüller, B.; Nürnberg, O.; Wolf, J.; Werner, H. Eur. J. Inorg. Chem. 1999, 613. (b) Nürnberg, O.; Werner, H. J. Organomet. Chem. 1993, 460, 163. (c) Tykwinski, R. R.; Stang, P. J. Organo metallics 1994, 13, 3203 .

(25) (a) Pavlik, S.; Gemel, C.; Slugovc, C.; Mereiter, K.; Schmid, R.; Kirchner, K. J. Organomet. Chem. 2001, 617-618, 301. (b) Pavlik, S. Mereiter, K. Schmid, R.; Kirchner, K. Organometallics 2003, 22, 1771.

(26) (a) Yoshida, M.; Jordan, R. F. Organometallics 1997, 16, 4508. (b) Crowther, D. J.; Baenziger, N. C.; Jordan, R. F. J. Am. Chem. Soc. 1991, 113, 1455 .

(27) Gil-Rubio, J.; Laubender, M.; Werner, H. Organometallics 2000 19, 1365. Bassetti, M.; Marini, S.; Díaz, J.; Gamasa, M. P.; Gimeno, J.; Rodríguez-Álvarez, Y.; García-Granda, S. Organometallics 2002 21, 4815. Becker, E.; Mereiter, K.; Puchberger, M.; Schmid, R.; Kirchner, K. Organometallics 2003, 22, 2124. 
reaction giving 8. Further reaction of 1-alkyne with complex $\mathbf{A}$ in $\mathrm{MeOH}$ affords the cationic vinylidene complex F. Coupling of the $\sigma$-acetylide with the vinylidene group results in formation of $(Z)$-butenynyl rhodium complex $\mathbf{G}$. Simple $\sigma$-bond metathesis of $\mathbf{G}$ and 1-alkyne discharges head-to-head (Z)-1,4-disubstituted enyne 8, regenerating $\mathbf{A}$. No dimerization reaction of alkyne $\mathbf{1 d}$ or $\mathbf{1 f}$ was observed in $\mathrm{MeOH}$. Actually, there are few cases of the reaction of 1-alkyne, which bears an electron-donating group with the transition metal to form the vinylidene complex. ${ }^{7 \mathrm{~b}}$ The presence of the electron-donating group may hinder coupling of the vinylidene ligand with the acetylide ligand, thus prohibiting formation of the dimer product. The catalytic system requires the presence of MeI, which is known to react readily with $\mathrm{PPh}_{3}$ to give phosphonium iodide. It is therefore less likely to have free dissociated $\mathrm{PPh}_{3}$ from the catalyst in the reaction mixture. Intermediate complexes $\mathbf{B}, \mathbf{C}, \mathbf{D}, \mathbf{F}$, and $\mathbf{G}$ in Schemes 1 and 2 are thus proposed to be derived from the dissociation of iodide from the catalyst consequently bearing cationic charge. ${ }^{24}$

Concluding Remarks. A rhodium intermediate captured from oxidative addition of MeI was used for selective dimerization of alkyne. Using the rhodium complex as a catalyst, the dimerization of various terminal arylalkynes in aprotic solvents (such as $\mathrm{CH}_{2-}$ $\mathrm{Cl}_{2}$, THF, and acetone) resulted in formation of $(E)-1,4-$ disubstituted enyne 6 in high stereoselectivity. However, when $\mathrm{MeOH}$ is used as a solvent, dimerization of 1-arylalkynes with an electron-withdrawing group gave the other stereoisomeric product ( $Z$ )-1,4-disubstituted enyne 8 in the presence of 0.1 equiv of MeI. With excess MeI, a competitive process, namely, oxidative additions of $\mathrm{MeI}$ and alkyne to the Rh metal center followed by reductive elimination, gave the alkylation product $\mathbf{4}$ of the terminal alkyne.

\section{Experimental Section}

General Procedures. All manipulations were performed under nitrogen using vacuum-line, drybox, and standard Schlenk techniques. $\mathrm{CH}_{2} \mathrm{Cl}_{2}$ and $\mathrm{CH}_{3} \mathrm{CN}$ were distilled from $\mathrm{CaH}_{2}$ and THF and diethyl ether from Na/diphenylketyl. All other solvents and reagents were of reagent grade and were used without further purification. The NMR spectra were recorded on a Bruker AC-200 or a Bruker AM-300WB FT-NMR spectrometer at room temperature (unless stated otherwise) and are reported in $\delta$ units with residual protons in the solvent as an internal standard $\left(\mathrm{CDCl}_{3}, \delta 7.24 ; \mathrm{CD}_{3} \mathrm{CN}, \delta 1.93 ; \mathrm{C}_{2} \mathrm{D}_{6-}\right.$ $\mathrm{CO}, \delta 2.04)$. FAB mass spectra were recorded on a JEOL SX102A spectrometer. X-ray diffraction studies and elemental analyses were carried out at the Regional Center of Analytical Instrument at National Taiwan University. Complexes Rh$(\mathrm{CO})\left(\mathrm{PPh}_{3}\right)_{2} \mathrm{Cl}(\mathbf{2})$ and $\left[\mathrm{Rh}(\mathrm{CO})_{2} \mathrm{Cl}\right]_{2}$ were prepared from $\mathrm{RhCl}_{3}$ according to the method reported in the literature. ${ }^{28}$

Synthesis of $\mathbf{R h}(\mathbf{C O})\left(\mathbf{P P h}_{3}\right)_{2} \mathbf{C} \equiv \mathbf{C P h}(\mathbf{3 a})$. Carbon monoxide was slowly bubbled through a mixture of $2(500 \mathrm{mg}, 0.72$ $\mathrm{mmol}$ ) and $\mathrm{HC} \equiv \mathrm{CPh}(\mathbf{1 a}, 80 \mathrm{mg}, 0.79 \mathrm{mmol})$ in $\mathrm{MeONa} / \mathrm{MeOH}$ (ca. $240 \mathrm{mg}$ of $\mathrm{MeONa}$ ). After $1.5 \mathrm{~h}$ bubbling was ceased and the reaction was allowed to proceed under a $\mathrm{CO}$ atmosphere for $18 \mathrm{~h}$ to yield a yellow powder, which was collected, washed with methanol, and identified as 3a (45 $\mathrm{mg}, 82 \%$ yield).

(28) (a) Colton, R.; Farthing, R. H.; Knapp, J. E. Aust. J. Chem. 1970 23, 1. (b) Schneider, R. L.; Watters, K. L. J. Catal. 1981, 72, 172. (c) Evans, D.; Osborn, J. A.; Wilkinson, G. Inorg. Synth. 1990, 28, 79. (d) Serron, S.; Nolan, S. P.; Moloy, K. G. Organometallics 1996, 15, 4301.
Spectroscopic data of 3a: ${ }^{1} \mathrm{H}$ NMR ( $d$-acetone): $\delta 7.80,7.71-$ 7.49, $7.44(\mathrm{~m}, \mathrm{Ph}) .{ }^{31} \mathrm{P}$ NMR ( $d$-acetone): $\delta 28.77(\mathrm{br}) . \mathrm{IR}\left(\mathrm{C}_{6} \mathrm{H}_{6}\right.$, $\left.\mathrm{cm}^{-1}\right): 1979\left(\mathrm{~s}, v_{\mathrm{C} \equiv \mathrm{O}}\right), 2122\left(\mathrm{w}, v_{\mathrm{C} \equiv \mathrm{C}}\right) . \mathrm{MS}(\mathrm{FAB}, \mathrm{NBA}, \mathrm{m} / z)$ : $757\left(\mathrm{M}^{+}+1\right), 728\left(\mathrm{M}^{+}-\mathrm{CO}\right), 655\left(\mathrm{M}^{+}-\mathrm{C} \equiv \mathrm{CC}_{6} \mathrm{H}_{5}\right), 627\left(\mathrm{M}^{+}\right.$ - $\mathrm{CO}-\mathrm{C} \equiv \mathrm{CC}_{6} \mathrm{H}_{5}$ ). Anal. Calcd for $\mathrm{RhP}_{2} \mathrm{C}_{45} \mathrm{H}_{35} \mathrm{O}$ : C, 71.43; $\mathrm{H}$, 4.66. Found: C, 71.41; H, 4.77. Complex $\mathrm{Rh}(\mathrm{CO})\left(\mathrm{PPh}_{3}\right)_{2} \mathrm{C} \equiv$ $\mathrm{C}\left(p-\mathrm{C}_{6} \mathrm{H}_{4} \mathrm{NO}_{2}\right)(\mathbf{3 b}, 510 \mathrm{mg}, 85 \%$ yield $)$ was similarly prepared from $2(520 \mathrm{mg}, 0.75 \mathrm{mmol})$ and $\mathbf{1 b}$ in $4 \mathrm{~h}$ under $\mathrm{CO}$. Spectroscopic data of 3b: ${ }^{1} \mathrm{H}$ NMR $\left(\mathrm{C}_{6} \mathrm{D}_{6}\right): \delta 7.90(\mathrm{~m}, \mathrm{Ph}), 7.62$ $\left(\mathrm{d}, J_{\mathrm{H}-\mathrm{H}}=8.68 \mathrm{~Hz}, \mathrm{Ph}, 2 \mathrm{H}\right), 7.05(\mathrm{~m}, \mathrm{Ph}), 6.33\left(\mathrm{~d}, J_{\mathrm{H}-\mathrm{H}}=8.68\right.$ $\mathrm{Hz}, \mathrm{Ph}, 2 \mathrm{H}) .{ }^{31} \mathrm{P}$ NMR $\left(\mathrm{C}_{6} \mathrm{D}_{6}\right): \delta 33.9\left(\mathrm{~d},{ }^{1} J_{\mathrm{Rh}-\mathrm{P}}=134.9 \mathrm{~Hz}\right)$. ${ }^{13} \mathrm{C} \mathrm{NMR}\left(\mathrm{C}_{6} \mathrm{D}_{6}\right): \delta 194.2\left(\mathrm{~d},{ }^{1} J_{\mathrm{Rh}-\mathrm{C}}=59.1 \mathrm{~Hz}, C \mathrm{O}\right), 122.07(\mathrm{~d}$, $\left.{ }^{2} J_{\mathrm{Rh}-\mathrm{C}}=11.2 \mathrm{~Hz}, C_{\beta}\right), 144.9,135.2,135.0,130.8,130.0,123.0$ (Ph). IR $\left(\mathrm{CH}_{2} \mathrm{Cl}_{2}, \mathrm{~cm}^{-1}\right): 1982\left(\mathrm{~s}, v_{\mathrm{C} \equiv \mathrm{O}}\right), 2089\left(\mathrm{w}, v_{\mathrm{C} \equiv \mathrm{C}}\right) . \mathrm{MS}$ $\left(\mathrm{FAB}^{+}, \mathrm{NBA}, \mathrm{m} / z\right): 801\left(\mathrm{M}^{+}\right), 773\left(\mathrm{M}^{+}-\mathrm{CO}\right), 655\left(\mathrm{M}^{+}-\mathrm{C} \equiv\right.$ $\left.\mathrm{CC}_{6} \mathrm{H}_{4}-\mathrm{NO}_{2}\right), 627\left(\mathrm{M}^{+}-\mathrm{CO}-\mathrm{C} \equiv \mathrm{CC}_{6} \mathrm{H}_{4} \mathrm{NO}_{2}\right)$. Anal. Calcd for $\mathrm{RhP}_{2} \mathrm{C}_{45} \mathrm{H}_{34} \mathrm{NO}_{3}$ : C, 67.42; H, 4.28; N, 1.75. Found: $\mathrm{C}$, 67.40; H, 4.37; N, 1.79 .

Synthesis of $\left[\mathrm{Rh}(\mathrm{CO})\left(\mathrm{PPh}_{3}\right)_{2}(\mathrm{C} \equiv \mathrm{CPh})\left(\mathrm{CH}_{2} \mathrm{CN}\right) \mathrm{I}\right]$ (5a). To complex 3a (115 mg, $0.15 \mathrm{mmol})$ in $\mathrm{CH}_{2} \mathrm{Cl}_{2}(15 \mathrm{~mL})$ was added dropwise $\mathrm{ICH}_{2} \mathrm{CN}(29 \mathrm{mg}, 0.165 \mathrm{mmol}$ ) at room temperature under nitrogen. After the reaction mixture was stirred for $18 \mathrm{~h}$, the color changed from yellow to orange-red, and the solvent was evaporated under vacuum. Purification by recrystallization from $\mathrm{CH}_{2} \mathrm{Cl}_{2} /$ hexane (1:10) gave a pale orange powder, $\mathbf{5 a}$ (115 mg, 83\% yield). Spectroscopic data of 5a: ${ }^{1} \mathrm{H}$ NMR ( $d$-acetone): $\delta 8.30,8.11,7.66,7.37(\mathrm{~m}, \mathrm{Ph}), 1.91$ $\left(\mathrm{m}, \mathrm{CH}_{2}\right) .{ }^{31} \mathrm{P}$ NMR $\left(d\right.$-acetone): $\delta 16.8\left(\mathrm{~d}, J_{\mathrm{Rh}-\mathrm{P}}=88.4 \mathrm{~Hz}\right)$. ${ }^{13} \mathrm{C} \mathrm{NMR}\left(\mathrm{CDCl}_{3}\right): \delta 184.5\left(\mathrm{dt},{ }^{1} J_{\mathrm{Rh}-\mathrm{C}}=47.0 \mathrm{~Hz},{ }^{2} \boldsymbol{J}_{\mathrm{P}-\mathrm{C}}=8.1\right.$ $\mathrm{Hz}, C \mathrm{O}), 114.3\left(\mathrm{dt},{ }^{2} J_{\mathrm{Rh}-\mathrm{C}}=7.8 \mathrm{~Hz},{ }^{3} J_{\mathrm{P}-\mathrm{C}}=3.5 \mathrm{~Hz}, C_{\beta}\right), 95.8$ $\left(\mathrm{dt},{ }^{1} J_{\mathrm{Rh}-\mathrm{C}}=35.8 \mathrm{~Hz},{ }^{2} J_{\mathrm{P}-\mathrm{C}}=19.8 \mathrm{~Hz}, C_{\alpha}\right),-6.3\left(\mathrm{dt},{ }^{1} J_{\mathrm{Rh}-\mathrm{C}}=\right.$ $\left.23.8 \mathrm{~Hz},{ }^{2} J_{\mathrm{P}-\mathrm{C}}=3.78 \mathrm{~Hz}, \mathrm{CH}_{2}\right), 134.8(\mathrm{t}, J=4.9 \mathrm{~Hz}), 128.1$ (t, $J=4.9 \mathrm{~Hz}), 132.1,131.8,131.4,130.6,130.2,126.0(\mathrm{~s}, C \mathrm{~N})$. IR (benzene, $\left.\mathrm{cm}^{-1}\right): 2206\left(\mathrm{w}, v_{\mathrm{C} \equiv \mathrm{N}}\right), 2123\left(\mathrm{w}, v_{\mathrm{C} \equiv \mathrm{C}}\right), 2088(\mathrm{~s}$, $\left.v_{\mathrm{C} \equiv 0}\right)$. MS (FAB, NBA, $\left.m / z\right): 924\left(\mathrm{M}^{+}+1\right), 855\left(\mathrm{M}^{+}-\mathrm{CO}-\right.$ $\left.\mathrm{CH}_{2} \mathrm{CN}\right), 768\left(\mathrm{M}^{+}-\mathrm{I}-\mathrm{CO}\right), 627\left(\mathrm{M}^{+}-\mathrm{I}-\mathrm{CO}-\mathrm{CH}_{2} \mathrm{CN}-\right.$ $\mathrm{C} \equiv \mathrm{CC}_{6} \mathrm{H}_{5}$ ). Anal. Calcd for $\mathrm{RhP}_{2} \mathrm{C}_{47} \mathrm{H}_{37} \mathrm{NOI}: \mathrm{C}, 61.12 ; \mathrm{H}, 4.04$; N, 1.52. Found: C, 61.20; H, 4.07; N, 1.59. Complex 5b (185 $\mathrm{mg})$ was similarly prepared from the reaction of $\mathbf{3 b}(175 \mathrm{mg}$, $0.22 \mathrm{mmol}$ ) with $\mathrm{ICH}_{2} \mathrm{CN}(42.5 \mathrm{mg}, 0.24 \mathrm{mmol})$ in $87 \%$ yield. Spectroscopic data of $\mathbf{5 b}:{ }^{1} \mathrm{H}$ NMR $\left(\mathrm{CDCl}_{3}\right)$ : $\delta 8.04,7.39(\mathrm{~m}$, $\mathrm{Ph}), 7.01\left(\mathrm{~d}, J_{\mathrm{H}-\mathrm{H}}=8.76 \mathrm{~Hz}, \mathrm{Ph}, 2 \mathrm{H}\right), 1.85\left(\mathrm{~m}, \mathrm{CH}_{2}, 2 \mathrm{H}\right) .{ }^{31} \mathrm{P}$ $\mathrm{NMR}\left(\mathrm{CDCl}_{3}\right): \delta 17.8\left(\mathrm{~d}, J_{\mathrm{Rh}-\mathrm{P}}=88.8 \mathrm{~Hz}\right),{ }^{13} \mathrm{C} \mathrm{NMR}\left(\mathrm{CDCl}_{3}\right)$ : $\delta 184.38\left(\mathrm{dt}, J_{\mathrm{Rh}-\mathrm{C}}=47 \mathrm{~Hz}, J_{\mathrm{P}-\mathrm{C}}=8.2 \mathrm{~Hz}, C \mathrm{O}\right), 145.8,134.8$ (t, $J=5 \mathrm{~Hz}), 133.7(\mathrm{~s}, C \mathrm{~N}), 131.7,131.4,131.1,130.9,130.6$, $128.2(\mathrm{t}, J=5 \mathrm{~Hz}) 123.7,113.5\left(\mathrm{dt}, J_{\mathrm{Rh}-\mathrm{C}}=8 \mathrm{~Hz}, J_{\mathrm{P}-\mathrm{C}}=3.4\right.$ $\left.\mathrm{Hz}, C_{\beta}\right), 108.5\left(\mathrm{dt}, J_{\mathrm{Rh}-\mathrm{C}}=36.5 \mathrm{~Hz}, J_{\mathrm{P}-\mathrm{C}}=19.7 \mathrm{~Hz}, \mathrm{Rh}-C_{\alpha}\right)$, $-5.98\left(\mathrm{dt}, J_{\mathrm{Rh}-\mathrm{C}}=23.7 \mathrm{~Hz}, J_{\mathrm{P}-\mathrm{C}}=4.0 \mathrm{~Hz} \mathrm{CH}_{2}\right)$. IR $\left(\mathrm{C}_{6} \mathrm{H}_{6}\right.$, $\left.\mathrm{cm}^{-1}\right): 2206\left(\mathrm{w}, v_{\mathrm{CN}}\right), 2123\left(\mathrm{w}, v_{\mathrm{CC}}\right), 2088\left(\mathrm{~s}, v_{\mathrm{CO}}\right) . \mathrm{MS}(\mathrm{FAB}$, NBA, $m / z): 969\left(\mathrm{M}^{+}+1\right), 900\left(\mathrm{M}^{+}-\mathrm{CO}-\mathrm{CH}_{2} \mathrm{CN}\right), 813\left(\mathrm{M}^{+}\right.$ - I - CO), $627\left(\mathrm{M}^{+}-\mathrm{I}-\mathrm{CO}-\mathrm{CH}_{2} \mathrm{CN}-\mathrm{C} \equiv \mathrm{CC}_{6} \mathrm{H}_{4} \mathrm{NO}_{2}\right)$. Anal. Calcd for $\mathrm{RhP}_{2} \mathrm{C}_{47} \mathrm{H}_{36} \mathrm{~N}_{2} \mathrm{O}_{3} \mathrm{I}$ : C, 58.28; H, 3.75; N, 2.89. Found: C, 58.30; H, 3.78; N, 2.91. Single crystals of $\mathbf{5 b}$ were grown by slow diffusion of hexane into a dichloromethane solution, giving yellow crystals suitable for X-ray diffraction analysis.

Rhodium-Catalyzed Coupling of MeI and Terminal Alkyne. A flask was charged with $1 \mathbf{a}(80 \mathrm{mg}, 0.79 \mathrm{mmol}), 2$ (28 mg, $0.04 \mathrm{mmol}$ ), $\mathrm{MeI}$ (116 mg, $0.82 \mathrm{mmol}$ ), and $\mathrm{MeOH}$ (15 $\mathrm{mL}$ ) in the presence of the base $\mathrm{MeONa}(140 \mathrm{mg})$. The reaction mixture was stirred for $10 \mathrm{~h}$, and then the solvent was evaporated under vacuum. The residue was extracted into 20 $\mathrm{mL}$ of $\mathrm{CH}_{2} \mathrm{Cl}_{2}$, which was filtered to remove $2, \mathrm{NaCl}$, excess $\mathrm{MeONa}$, and other insoluble solids. The solvent was dried under vacuum and the product purified by column chromatography on silica gel eluted with ether/hexane (1:9), affording organic compound $\mathbf{4 a}(81 \mathrm{mg}, 88 \%)$. Spectroscopic data of $\mathbf{4 a}$ : ${ }^{1} \mathrm{H} \mathrm{NMR}\left(\mathrm{CDCl}_{3}\right): \delta 7.10-6.81(\mathrm{~m}, \mathrm{Ph}), 2.03\left(\mathrm{~s}, \mathrm{CH}_{3}\right) . \mathrm{MS}(\mathrm{EI}$, $\mathrm{m} / \mathrm{z}): 116.1\left(\mathrm{M}^{+}\right)$.

Typical Procedure for Dimerization of Arylacetylene. To a flask charged with $2(20 \mathrm{mg}, 0.029 \mathrm{mmol}), \mathrm{K}_{2} \mathrm{CO}_{3}(4.0 \mathrm{~g}$, 
$29 \mathrm{mmol})$, and $\mathrm{MeI}(208 \mathrm{mg}, 1.49 \mathrm{mmol})$ in $\mathrm{CH}_{2} \mathrm{Cl}_{2}(15 \mathrm{~mL})$ was added $1 \mathbf{a}(302 \mathrm{mg}, 2.9 \mathrm{mmol})$ by a syringe. The reaction mixture was stirred for $18 \mathrm{~h}$ at room temperature, and the solvent was removed under vacuum. The residue was extracted into $20 \mathrm{~mL}$ of $\mathrm{CH}_{2} \mathrm{Cl}_{2}$, which was filtered to remove organometallic compounds, salt, and $\mathrm{K}_{2} \mathrm{CO}_{3}$. The solution was dried under vacuum and the residue purified by column chromatography eluted by ether/hexane (1:9). The solution was dried under vacuum, and the major product was identified as $\mathbf{6 a}$ (226 mg, 75\% yield). Minor products $\mathbf{7 a}$ and $\mathbf{4 a}$ are identified by NMR and are not isolated. Spectroscopic data for $6 \mathbf{6 a}:{ }^{1} \mathrm{H}$ $\operatorname{NMR}\left(\mathrm{CDCl}_{3}\right): \delta 7.45-7.38,7.35-7.29(\mathrm{~m}, \mathrm{Ph}, 10 \mathrm{H}), 7.05(\mathrm{~d}$, $\left.=\mathrm{CH},{ }^{3} J_{\mathrm{H}-\mathrm{H}}=16.2 \mathrm{~Hz}\right), 6.39\left(\mathrm{~d},=\mathrm{CH},{ }^{3} J_{\mathrm{H}-\mathrm{H}}=16.2 \mathrm{~Hz}\right),{ }^{13} \mathrm{C}$ $\operatorname{NMR}\left(\mathrm{CDCl}_{3}\right): \delta 141.2(\mathrm{~s}, C-\mathrm{Ar}), 108.1(\mathrm{~s},-C=\mathrm{C}-\mathrm{Ar}), 91.7$ (s, $\mathrm{Ar}-C \equiv \mathrm{C}-$ ), 88.9 (s, $\mathrm{Ar}-\mathrm{C} \equiv C-), 136.3,131.5,128.7,128.6$, 128.3, 128.1, 126.3, 123.4 (all singlet, phenyl). MS (FAB, $\mathrm{m} / \mathrm{z}): 204.1\left(\mathrm{M}^{+}\right)$.

Dimerization of $1 \mathbf{b}$ to 6 b. A similar reaction using 2 (20 $\mathrm{mg}, 0.029 \mathrm{mmol}), \mathrm{K}_{2} \mathrm{CO}_{3}(800 \mathrm{mg}, 5.8 \mathrm{mmol})$, THF $(10 \mathrm{~mL})$, $\mathrm{HC} \equiv \mathrm{C}\left(p-\mathrm{C}_{6} \mathrm{H}_{4} \mathrm{NO}_{2}\right)(\mathbf{1 b}, 85 \mathrm{mg}, 0.58 \mathrm{mmol})$, and $\mathrm{MeI}(246 \mathrm{mg}$, $1.74 \mathrm{mmol}$ ) gave a mixture of $\mathbf{6 b}, \mathbf{7 b}$, and $\mathbf{4 b}$ in a $60: 15: 25$ ratio. Compound $\mathbf{6 b}(44.2 \mathrm{mg})$ was obtained in $52 \%$ isolated yield. Spectroscopic data for 6b: ${ }^{1} \mathrm{H}$ NMR $\left(\mathrm{CDCl}_{3}\right): \delta 8.23(\mathrm{~d}$, $\left.{ }^{3} J_{\mathrm{H}-\mathrm{H}}=8.7 \mathrm{~Hz}\right), 8.22\left(\mathrm{~d},{ }^{3} \boldsymbol{J}_{\mathrm{H}-\mathrm{H}}=8.7 \mathrm{~Hz}\right), 7.62\left(\mathrm{~d},{ }^{3} J_{\mathrm{H}-\mathrm{H}}=8.7\right.$ $\mathrm{Hz}), 7.58\left(\mathrm{~d},{ }^{3} J_{\mathrm{H}-\mathrm{H}}=8.7 \mathrm{~Hz}\right), 7.17\left(\mathrm{~d},=\mathrm{CH},{ }^{3} J_{\mathrm{H}-\mathrm{H}}=16.2 \mathrm{~Hz}\right)$, $6.56\left(\mathrm{~d},=\mathrm{CH},{ }^{3} J_{\mathrm{H}-\mathrm{H}}=16.2 \mathrm{~Hz}\right) .{ }^{13} \mathrm{C} \mathrm{NMR}\left(\mathrm{CDCl}_{3}\right): \delta 142.5(\mathrm{~s}$, $-\mathrm{C}=C-\mathrm{Ar}), 112.5(\mathrm{~s},-C=\mathrm{C}-\mathrm{Ar}), 93.5(\mathrm{~s}, \mathrm{Ar}-C \equiv \mathrm{C}-), 92.7(\mathrm{~s}$, $\mathrm{Ar}-\mathrm{C} \equiv \mathrm{C}-\mathrm{)}, 148.4,147.8141 .1,132.9,130.2,127.6,124.8$, 124.3 (all singlet, phenyl). MS (FAB, $\mathrm{m} / z)$ : $294.0\left(\mathrm{M}^{+}\right)$.

A similar reaction using 2 (10 mg, $0.0145 \mathrm{mmol}), \mathrm{K}_{2} \mathrm{CO}_{3}(2.0$ g, $14.5 \mathrm{mmol}), \mathrm{CH}_{2} \mathrm{Cl}_{2}(5 \mathrm{~mL})$, $1 \mathrm{e}(184 \mathrm{mg}, 1.45 \mathrm{mmol})$, and MeI (20 mg, $0.145 \mathrm{mmol})$ gave 6e $(99 \mathrm{mg})$ in $54 \%$ yield. Spectroscopic data for 6e: ${ }^{1} \mathrm{H}$ NMR $\left(\mathrm{CDCl}_{3}\right): \delta 7.63\left(\mathrm{~d},{ }^{3} J_{\mathrm{H}-\mathrm{H}}\right.$ $=6.2 \mathrm{~Hz}), 7.62\left(\mathrm{~d},{ }^{3} J_{\mathrm{H}-\mathrm{H}}=6.2 \mathrm{~Hz}\right), 7.54\left(\mathrm{~d},{ }^{3} J_{\mathrm{H}-\mathrm{H}}=8.5 \mathrm{~Hz}\right)$, $7.51\left(\mathrm{~d},{ }^{3} \mathrm{~J}_{\mathrm{H}-\mathrm{H}}=8.5 \mathrm{~Hz}\right), 7.08\left(\mathrm{~d},=\mathrm{CH},{ }^{3} J_{\mathrm{H}-\mathrm{H}}=16.2 \mathrm{~Hz}\right), 6.50$ $\left(\mathrm{d},=\mathrm{CH},{ }^{3} J_{\mathrm{H}-\mathrm{H}}=16.2 \mathrm{~Hz}\right),{ }^{13} \mathrm{C}$ NMR $\left(\mathrm{CDCl}_{3}\right): \delta 140.7(\mathrm{~s}$, $-\mathrm{C}=C-\mathrm{Ar}), 111.1(\mathrm{~s},-C=\mathrm{C}-\mathrm{Ar}), 92.2(\mathrm{~s}, \mathrm{Ar}-C \equiv \mathrm{C}-), 92.0(\mathrm{~s}$, $\mathrm{Ar}-\mathrm{C} \equiv \mathrm{C}-), 118.5(\mathrm{CN}), 118.3(\mathrm{CN}), 140.1,133.0,132.6,132.2$, $132.1,132.0,127.2,126.8,112.1,111.8$ (all singlet, phenyl). MS (FAB, $m / z): 255.2\left(\mathrm{M}^{+}+1\right)$.

Compound $\mathbf{6 d}(63 \mathrm{mg})$ was obtained from $2(20 \mathrm{mg}, 0.029$ $\mathrm{mmol}), \mathrm{MeONa}(156 \mathrm{mg}, 2.9 \mathrm{mmol})$, THF (10 mL), MeI (250 $\mathrm{mg}, 1.74 \mathrm{mmol})$, and $\mathbf{1 d}(70 \mathrm{mg}, 0.58 \mathrm{mmol})$ in $90 \%$ yield. Spectroscopic data for $6 \mathbf{d}:{ }^{1} \mathrm{H}$ NMR $\left(\mathrm{CDCl}_{3}\right): \delta 7.36\left(\mathrm{~d},{ }^{3} J_{\mathrm{H}-\mathrm{H}}\right.$ $=8.0 \mathrm{~Hz}), 7.32\left(\mathrm{~d},{ }^{3} J_{\mathrm{H}-\mathrm{H}}=8.0 \mathrm{~Hz}\right), 7.15\left(\mathrm{~d},{ }^{3} J_{\mathrm{H}-\mathrm{H}}=7.75 \mathrm{~Hz}\right)$, $7.13\left(\mathrm{~d},{ }^{3} J_{\mathrm{H}-\mathrm{H}}=7.75 \mathrm{~Hz}\right), 7.00\left(\mathrm{~d},=\mathrm{CH},{ }^{3} J_{\mathrm{H}-\mathrm{H}}=16.2 \mathrm{~Hz}\right)$, $6.33\left(\mathrm{~d},=\mathrm{CH},{ }^{3} J_{\mathrm{H}-\mathrm{H}}=16.2 \mathrm{~Hz}\right), 2.34\left(\mathrm{~s}, \mathrm{CH}_{3}, 6 \mathrm{H}\right) .{ }^{13} \mathrm{C} \mathrm{NMR}$ $\left(\mathrm{CDCl}_{3}\right): \delta 140.9(\mathrm{~s},-\mathrm{C}=C-\mathrm{Ar}), 107.2(\mathrm{~s},-C=\mathrm{C}-\mathrm{Ar}), 91.6$ $(\mathrm{s}, \mathrm{Ar}-\mathrm{C} \equiv \mathrm{C}-), 88.4(\mathrm{~s}, \mathrm{Ar}-\mathrm{C} \equiv \mathrm{C}-), 21.5\left(\mathrm{~s}, \mathrm{CH}_{3}\right), 21.3\left(\mathrm{~s}, \mathrm{CH}_{3}\right)$, 138.6, 138.2, 133.7, 131.6, 129.4, 129.1, 126.2, 120.4, 119.4 (all singlet, phenyl). MS (FAB, $m / z): 232.1\left(\mathrm{M}^{+}\right)$.

Compound $6 \mathbf{f}(172 \mathrm{mg})$ was obtained from 2 (10 mg, 0.0145 $\mathrm{mmol}), \mathrm{MeONa}$ (391 mg, $7.25 \mathrm{mmol}), \mathrm{CH}_{2} \mathrm{Cl}_{2}(5 \mathrm{~mL})$, $\mathbf{1 f}(210$ $\mathrm{mg}, 1.45 \mathrm{mmol}$ ), and $\mathrm{MeI}(20 \mathrm{mg}, 0.145 \mathrm{mmol})$ in $82 \%$ yield. Spectroscopic data for $6 \mathbf{6}:{ }^{1} \mathrm{H}$ NMR $\left(\mathrm{CDCl}_{3}\right): \delta 7.33\left(\mathrm{~d},{ }^{3} \boldsymbol{J}_{\mathrm{H}-\mathrm{H}}\right.$ $=9.2 \mathrm{~Hz}), 7.30\left(\mathrm{~d},{ }^{3} J_{\mathrm{H}-\mathrm{H}}=9.2 \mathrm{~Hz}\right), 6.67\left(\mathrm{~d},{ }^{3} J_{\mathrm{H}-\mathrm{H}}=9.1 \mathrm{~Hz}\right)$, $6.64\left(\mathrm{~d},{ }^{3} J_{\mathrm{H}-\mathrm{H}}=9.1 \mathrm{~Hz}\right), 6.90\left(\mathrm{~d},{ }^{3} J_{\mathrm{H}-\mathrm{H}}=16.2 \mathrm{~Hz}\right), 6.18(\mathrm{~d}$, $\left.{ }^{3} J_{\mathrm{H}-\mathrm{H}}=16.2 \mathrm{~Hz}\right) \cdot{ }^{13} \mathrm{C} \mathrm{NMR}\left(\mathrm{CDCl}_{3}\right): \delta 139.8(\mathrm{~s},-\mathrm{C}=C-\mathrm{Ar})$, $103.8(\mathrm{~s},-C=\mathrm{C}-\mathrm{Ar}), 91.5(\mathrm{~s}, \mathrm{Ar}-C \equiv \mathrm{C}-), 87.8(\mathrm{~s}, \mathrm{Ar}-$ $\mathrm{C} \equiv C-), 40.3\left(\mathrm{NMe}_{2}\right), 40.2\left(\mathrm{NMe}_{2}\right), 150.4,149.8,139.8,132.4$, $127.3,112.2,111.9,110.8$ (all singlet, phenyl). MS (FAB, $\mathrm{m} / \mathrm{z}): 290.1\left(\mathrm{M}^{+}\right)$.

Compound $6 \mathbf{g}$ (182.7 mg) was prepared from 2 (40 mg, 0.058 $\mathrm{mmol}), \mathrm{K}_{2} \mathrm{CO}_{3}$ (1.6 g, $\left.11.6 \mathrm{mmol}\right)$, THF (10 mL), MeI (492 mg, $3.48 \mathrm{mmol}$ ), and $1 \mathrm{~g}(203 \mathrm{mg}, 1.16 \mathrm{mmol})$ in $90 \%$ yield. Spectroscopic data for $6 \mathrm{~g}:{ }^{1} \mathrm{H}$ NMR $\left(\mathrm{CDCl}_{3}\right): \delta 7.68-7.46(\mathrm{~m}$, phenyl, 8H), $7.11\left(\mathrm{~d},{ }^{3} \boldsymbol{J}_{\mathrm{H}-\mathrm{H}}=16.2 \mathrm{~Hz}\right), 6.47\left(\mathrm{~d},{ }^{3} J_{\mathrm{H}-\mathrm{H}}=16.2\right.$ $\mathrm{Hz}) .{ }^{13} \mathrm{C} \mathrm{NMR}\left(\mathrm{CDCl}_{3}\right): \delta 140.1(\mathrm{~s},-\mathrm{C}=\mathrm{C}-\mathrm{Ar}), 110.2(\mathrm{~s}$, $-C=\mathrm{C}-\mathrm{Ar}), 91.5(\mathrm{~s}, \mathrm{Ar}-C \equiv \mathrm{C}-), 90.5(\mathrm{~s}, \mathrm{Ar}-\mathrm{C} \equiv C-), 139.4$, 137.0, 134.2, 132.0, 131.8, 130.8, 130.3, 129.9, 129.7, 128.4, $127.1,126.8,125.8\left(\mathrm{q}, J_{\mathrm{FC}}=3.7 \mathrm{~Hz}\right), 125.4\left(\mathrm{q}, J_{\mathrm{FC}}=3.7 \mathrm{~Hz}\right)$. MS (FAB, $m / z): 340.0\left(\mathrm{M}^{+}\right)$.

Compound $6 \mathbf{h}(55 \mathrm{mg})$ was synthesized from 2 (40 mg, 0.058 $\mathrm{mmol}), \mathrm{K}_{2} \mathrm{CO}_{3}(1.6 \mathrm{~g}, 11.6 \mathrm{mmol}), \mathrm{CH}_{2} \mathrm{Cl}_{2}(5 \mathrm{~mL}), \mathrm{MeI}(492$ $\mathrm{mg}, 3.48 \mathrm{mmol})$, and $\mathbf{1 h}(142 \mathrm{mg}, 1.16 \mathrm{mmol})$ in $39 \%$ yield. Spectroscopic data for $\mathbf{6 h}:{ }^{1} \mathrm{H}$ NMR $\left(\mathrm{CDCl}_{3}\right): \delta 7.44-7.34(\mathrm{~m}$, $\mathrm{Ph}, 4 \mathrm{H}), 7.04 \sim 6.94(\mathrm{~m}, \mathrm{Ph}, 4 \mathrm{H}), 7.00\left(\mathrm{~d},=\mathrm{CH},{ }^{3} J_{\mathrm{H}-\mathrm{H}}=16.2\right.$ $\mathrm{Hz}), 6.28\left(\mathrm{~d},=\mathrm{CH},{ }^{3} J_{\mathrm{H}-\mathrm{H}}=16.2 \mathrm{~Hz}\right) .{ }^{13} \mathrm{C} \mathrm{NMR}\left(\mathrm{CDCl}_{3}\right): \delta 140.0$ $(\mathrm{s},-\mathrm{C}=C-\mathrm{Ar}), 107.7(\mathrm{~s},-C=\mathrm{C}-\mathrm{Ar}), 90.1(\mathrm{~s}, \mathrm{Ar}-C \equiv \mathrm{C}-), 88.3$ $(\mathrm{s}, \mathrm{Ar}-\mathrm{C} \equiv \mathrm{C}-), 164.6\left(\mathrm{~d},{ }^{1} J_{\mathrm{F}-\mathrm{C}}=36.6 \mathrm{~Hz}\right), 161.3\left(\mathrm{~d},{ }^{1} J_{\mathrm{F}-\mathrm{C}}=\right.$ $37.6 \mathrm{~Hz}), 133.4\left(\mathrm{~d},{ }^{3} J_{\mathrm{F}-\mathrm{C}}=8.3 \mathrm{~Hz}\right), 132.5\left(\mathrm{~d}, J_{\mathrm{F}-\mathrm{C}}=3.3 \mathrm{~Hz}\right)$, $128.0\left(\mathrm{~d},{ }^{3} J_{\mathrm{F}-\mathrm{C}}=8.2 \mathrm{~Hz}\right), 119.5\left(\mathrm{~d}, J_{\mathrm{F}-\mathrm{C}}=3.5 \mathrm{~Hz}\right), 115.9(\mathrm{~d}$, $\left.{ }^{2} J_{\mathrm{F}-\mathrm{C}}=21.8 \mathrm{~Hz}\right), 115.8\left(\mathrm{~d},{ }^{2} J_{\mathrm{F}-\mathrm{C}}=22.0 \mathrm{~Hz}\right) . \mathrm{MS}(\mathrm{FAB}, \mathrm{m} / \mathrm{z})$ : $240.0\left(\mathrm{M}^{+}\right)$.

Compound $6 \mathbf{i}$ ( $369.2 \mathrm{mg}$ ) was prepared from $2(20 \mathrm{mg}, 0.029$ $\mathrm{mmol}), \mathrm{K}_{2} \mathrm{CO}_{3}(3.2 \mathrm{~g}, 23.2 \mathrm{mmol}), \mathrm{CH}_{2} \mathrm{Cl}_{2}(10 \mathrm{~mL}), \mathbf{1 i}(420 \mathrm{mg}$, $2.32 \mathrm{mmol}$ ), and $\mathrm{MeI}(83 \mathrm{mg}, 0.58 \mathrm{mmol}$ ) in $88 \%$ yield. Spectroscopic data for 6i: ${ }^{1} \mathrm{H}$ NMR $\left(\mathrm{CDCl}_{3}\right): \delta 7.47\left(\mathrm{~d},{ }^{3} J_{\mathrm{H}-\mathrm{H}}\right.$ $=8.5 \mathrm{~Hz}), 7.46\left(\mathrm{~d},{ }^{3} J_{\mathrm{H}-\mathrm{H}}=8.5 \mathrm{~Hz}\right), 7.32\left(\mathrm{~d},{ }^{3} J_{\mathrm{H}-\mathrm{H}}=8.0 \mathrm{~Hz}\right)$, $7.28\left(\mathrm{~d},{ }^{3} J_{\mathrm{H}-\mathrm{H}}=8.0 \mathrm{~Hz}\right), 6.99\left(\mathrm{~d},=\mathrm{CH},{ }^{3} J_{\mathrm{H}-\mathrm{H}}=16.2 \mathrm{~Hz}\right), 6.36$ $\left(\mathrm{d},=\mathrm{CH},{ }^{3} J_{\mathrm{H}-\mathrm{H}}=16.2 \mathrm{~Hz}\right),{ }^{13} \mathrm{C} \operatorname{NMR}\left(\mathrm{CDCl}_{3}\right): \delta 140.3(\mathrm{~s}$, $-\mathrm{C}=C-\mathrm{Ar}), 108.6(\mathrm{~s},-C=\mathrm{C}-\mathrm{Ar}), 91.2(\mathrm{~s}, \mathrm{Ar}-C \equiv \mathrm{C}-), 89.7(\mathrm{~s}$, $\mathrm{Ar}-\mathrm{C} \equiv C-), 135.1,132.9,131.9,131.6,127.7,122.7,122.6$, 122.2 (all singlet, phenyl). $\mathrm{MS}(\mathrm{FAB}, \mathrm{m} / z)$ : $362.9\left(\mathrm{M}^{+}+1\right)$.

Compound $6 \mathbf{j}$ ( $254 \mathrm{mg}$ ) was prepared from 2 (10 mg, 0.0145 $\mathrm{mmol}), \mathrm{K}_{2} \mathrm{CO}_{3}(2 \mathrm{~g}, 14.5 \mathrm{mmol}), \mathrm{CH}_{2} \mathrm{Cl}_{2}(5 \mathrm{~mL}), \mathrm{HC} \equiv \mathrm{C}\left(p-\mathrm{C}_{6} \mathrm{H}_{4} \mathrm{I}\right)$ $\mathbf{1 j}$ (330 mg, $1.45 \mathrm{mmol}$ ), and $\mathrm{MeI}(20 \mathrm{mg}, 0.145 \mathrm{mmol})$ in $77 \%$ yield. Spectroscopic data for 6j: ${ }^{1} \mathrm{H}$ NMR $\left(\mathrm{CDCl}_{3}\right): \delta 7.67(\mathrm{~d}$, $\left.{ }^{3} J_{\mathrm{H}-\mathrm{H}}=8.4 \mathrm{~Hz}\right), 7.66\left(\mathrm{~d},{ }^{3} \boldsymbol{J}_{\mathrm{H}-\mathrm{H}}=8.4 \mathrm{~Hz}\right), 7.17\left(\mathrm{~d},{ }^{3} \boldsymbol{J}_{\mathrm{H}-\mathrm{H}}=8.4\right.$ $\mathrm{Hz}), 7.14\left(\mathrm{~d},{ }^{3} J_{\mathrm{H}-\mathrm{H}}=8.4 \mathrm{~Hz}\right), 6.96\left(\mathrm{~d},=\mathrm{CH},{ }^{3} J_{\mathrm{H}-\mathrm{H}}=16.2 \mathrm{~Hz}\right)$, $6.36\left(\mathrm{~d},=\mathrm{CH},{ }^{3} \mathrm{~J}_{\mathrm{H}-\mathrm{H}}=16.2 \mathrm{~Hz}\right),{ }^{13} \mathrm{C} \mathrm{NMR}\left(\mathrm{CDCl}_{3}\right): \delta 140.5(\mathrm{~s}$, $-\mathrm{C}=C-\mathrm{Ar}), 108.7(\mathrm{~s},-C=\mathrm{C}-\mathrm{Ar}), 91.5(\mathrm{~s}, \mathrm{Ar}-C \equiv \mathrm{C}-), 90.0(\mathrm{~s}$, $\mathrm{Ar}-\mathrm{C} \equiv C-), 137.9,137.6,135.6,132.9,127.9,122.7,94.3,94.2$ (all singlet, phenyl). MS (FAB, $\mathrm{m} / z)$ : $455.8\left(\mathrm{M}^{+}\right)$.

Compound 6c (44 mg) was prepared from $2 \mathbf{a}(20 \mathrm{mg}, 0.029$ $\mathrm{mmol}), \mathrm{K}_{2} \mathrm{CO}_{3}(800 \mathrm{mg}, 5.8 \mathrm{mmol})$, THF $(10 \mathrm{~mL}), \mathbf{1 c}(74 \mathrm{mg}$, $0.585 \mathrm{mmol}$ ), and MeI (166 mg, $1.16 \mathrm{mmol})$ in $60 \%$ yield. Spectroscopic data for 6c: ${ }^{1} \mathrm{H}$ NMR $\left(\mathrm{CDCl}_{3}\right): \delta 10.0(\mathrm{~s}, \mathrm{COH}$, $1 \mathrm{H}), 9.99(\mathrm{~s}, \mathrm{COH}, 1 \mathrm{H}), 7.87\left(\mathrm{~d},{ }^{3} J_{\mathrm{H}-\mathrm{H}}=8.1 \mathrm{~Hz}\right), 7.86\left(\mathrm{~d},{ }^{3} J_{\mathrm{H}-\mathrm{H}}\right.$ $=8.1 \mathrm{~Hz}), 7.62\left(\mathrm{~d},{ }^{3} J_{\mathrm{H}-\mathrm{H}}=8.4 \mathrm{~Hz}\right), 7.58\left(\mathrm{~d},{ }^{3} J_{\mathrm{H}-\mathrm{H}}=8.4 \mathrm{~Hz}\right)$, $7.14\left(\mathrm{~d},=\mathrm{CH},{ }^{3} J_{\mathrm{H}-\mathrm{H}}=16.2 \mathrm{~Hz}\right), 6.56\left(\mathrm{~d},=\mathrm{CH},{ }^{3} J_{\mathrm{H}-\mathrm{H}}=16.2\right.$ $\mathrm{Hz}) .{ }^{13} \mathrm{C} \mathrm{NMR}\left(\mathrm{CDCl}_{3}\right): \delta 141.7(\mathrm{~s},-\mathrm{C}=\mathrm{C}-\mathrm{Ar}), 111.3(\mathrm{~s},-C=$ $\mathrm{C}-\mathrm{Ar}), 92.7(\mathrm{~s}, \mathrm{Ar}-\mathrm{C} \equiv \mathrm{C}), 92.3(\mathrm{~s}, \mathrm{Ar}-\mathrm{C} \equiv \mathrm{C}-$ ), 191.4 (s, COH), 191.3 (s, COH), 141.1, 136.3, 135.6, 132.1, 130.2, 129.8, 129.6, 126.9 (all singlet, phenyl). MS (FAB, $m / z): 261.1\left(\mathrm{M}^{+}+1\right)$.

Compound 7k $(176 \mathrm{mg})$ was prepared in $72 \%$ yield from 2 (20 mg, $0.029 \mathrm{mmol}), \mathrm{K}_{2} \mathrm{CO}_{3}(1.6 \mathrm{~g}, 11.6 \mathrm{mmol}), \mathrm{CH}_{2} \mathrm{Cl}_{2}(5 \mathrm{~mL})$, $1 \mathbf{k}$ (245 mg, $2.9 \mathrm{mmol})$, and $\mathrm{MeI}(1.23 \mathrm{~g}, 8.7 \mathrm{mmol})$. Spectroscopic data for 7k: ${ }^{1} \mathrm{H}$ NMR $\left(\mathrm{CDCl}_{3}\right): \delta 5.18\left(\mathrm{~d},{ }^{2} \boldsymbol{J}_{\mathrm{H}-\mathrm{H}}=2.06\right.$ $\mathrm{Hz}), 5.01\left(\mathrm{~d},{ }^{2} J_{\mathrm{H}-\mathrm{H}}=2.06 \mathrm{~Hz}\right), 2.28\left(\mathrm{~d},{ }^{3} J_{\mathrm{H}-\mathrm{H}}=6.72 \mathrm{~Hz}, 2 \mathrm{H}\right)$, $2.09\left(\mathrm{~d},{ }^{3} J_{\mathrm{H}-\mathrm{H}}=7.44 \mathrm{~Hz}, 2 \mathrm{H}\right), 1.50-1.27(\mathrm{~m}, 8 \mathrm{H}), 0.93-0.84$ $(\mathrm{m}, 6 \mathrm{H}) . \mathrm{MS}(\mathrm{FAB}, \mathrm{m} / \mathrm{z}): 164.0\left(\mathrm{M}^{+}\right)$.

Preparation of 8a. A flask was charged with $2(20 \mathrm{mg}$, $0.029 \mathrm{mmol}), \mathrm{K}_{2} \mathrm{CO}_{3}(4.0 \mathrm{~g}, 29 \mathrm{mmol})$, and $\mathrm{MeOH}(10 \mathrm{~mL})$, and then $\mathrm{MeI}$ (40 mg, $0.29 \mathrm{mmol})$ and $1 \mathbf{a}(302 \mathrm{mg}, 2.9 \mathrm{mmol})$ were added by a syringe. The reaction mixture was stirred at room temperature, and the solvent was removed under vacuum. The residue was extracted into $20 \mathrm{~mL}$ of $\mathrm{CH}_{2} \mathrm{Cl}_{2}$, which was filtered to remove organometallic compounds, salt, and $\mathrm{K}_{2} \mathrm{CO}_{3}$. The solution was dried under vacuum and the residue purified by column chromatography eluted by ether/hexane (1:9). The solution was dried under vacuum, and the major product was identified as $\mathbf{8 a}(190 \mathrm{mg})$ in $63 \%$ yield. Spectroscopic data for 8a: ${ }^{1} \mathrm{H}$ NMR $\left(\mathrm{CDCl}_{3}\right): \delta 7.93\left(\mathrm{~d},{ }^{3} \boldsymbol{J}_{\mathrm{H}-\mathrm{H}}=8.7 \mathrm{~Hz}, 2 \mathrm{H}\right), 7.48$ $(\mathrm{m}, \mathrm{Ph}, 2 \mathrm{H}), 7.46-7.00(\mathrm{~m}, \mathrm{Ph}, 5 \mathrm{H}), 6.71\left(\mathrm{~d},{ }^{3} J_{\mathrm{H}-\mathrm{H}}=12.0\right.$ $\mathrm{Hz},=\mathrm{CH}), 5.93\left(\mathrm{~d},{ }^{3} J_{\mathrm{H}-\mathrm{H}}=12.0 \mathrm{~Hz},=\mathrm{CH}\right) .{ }^{13} \mathrm{C} \mathrm{NMR}\left(\mathrm{CDCl}_{3}\right)$ : $\delta 141.8(\mathrm{~s}, \mathrm{C}=C \mathrm{Ar}), 108.0(\mathrm{~s}, C=\mathrm{CAr}), 96.4(\mathrm{~s}, \operatorname{Ar} C \equiv \mathrm{C}), 88.8$ (s, $\mathrm{ArC} \equiv C), 139.3,137.1,132.0,129.4,129.0,129.0,128.9$, 128.8 (all singlet, phenyl). MS (FAB, $\mathrm{m} / \mathrm{z})$ : $204.0\left(\mathrm{M}^{+}\right)$.

Using the same procedure compound 8e (151 mg) was obtained in $82 \%$ yield from 1 e (184 mg, $1.45 \mathrm{mmol})$. Spectro- 
scopic data for 8e: ${ }^{1} \mathrm{H}$ NMR $\left(\mathrm{CDCl}_{3}\right): \delta 7.94\left(\mathrm{~d},{ }^{3} J_{\mathrm{H}-\mathrm{H}}=8.46\right.$ $\mathrm{Hz}), 7.67\left(\mathrm{~d},{ }^{3} J_{\mathrm{H}-\mathrm{H}}=8.06 \mathrm{~Hz}\right), 7.65\left(\mathrm{~d},{ }^{3} J_{\mathrm{H}-\mathrm{H}}=8.06 \mathrm{~Hz}\right), 7.53$ $\left(\mathrm{d},{ }^{3} J_{\mathrm{H}-\mathrm{H}}=8.46 \mathrm{~Hz}\right), 6.80\left(\mathrm{~d},=\mathrm{CH},{ }^{3} J_{\mathrm{H}-\mathrm{H}}=12.0 \mathrm{~Hz}\right), 6.10(\mathrm{~d}$, $\left.=\mathrm{CH},{ }^{3} J_{\mathrm{H}-\mathrm{H}}=12.0 \mathrm{~Hz}\right) .{ }^{13} \mathrm{C} \mathrm{NMR}\left(\mathrm{CDCl}_{3}\right): \delta 140.3(\mathrm{~s}$, $\mathrm{C}=C \operatorname{Ar}), 112.0(\mathrm{~s}, C=\mathrm{CAr}), 95.5(\mathrm{~s}, \operatorname{Ar} C \equiv \mathrm{C}), 91.2(\mathrm{~s}, \operatorname{ArC} \equiv C)$, $118.6(\mathrm{CN}), 118.2(\mathrm{CN}), 138.2,132.2,132.1,132.0,129.1,127.5$, 112.2, 111.9, 110.3 (all singlet, $\mathrm{Ph}$ ). $\mathrm{MS}(\mathrm{FAB}, \mathrm{m} / \mathrm{z}): 254.0\left(\mathrm{M}^{+}\right)$. Compound $8 \mathrm{~g}$ (224 $\mathrm{mg}$ ) was similarly obtained in $91 \%$ yield from $1 \mathbf{g}$ (246.7 mg, $1.45 \mathrm{mmol})$. Spectroscopic data for $\mathbf{8 g}:{ }^{1} \mathrm{H}$ $\operatorname{NMR}\left(\mathrm{CDCl}_{3}\right): \delta 7.99\left(\mathrm{~d},{ }^{3} J_{\mathrm{H}-\mathrm{H}}=8.2 \mathrm{~Hz}\right), 7.65-7.54(\mathrm{~m}, \mathrm{Ph}$, $6 \mathrm{H}), 6.80\left(\mathrm{~d},=\mathrm{CH},{ }^{3} J_{\mathrm{H}-\mathrm{H}}=11.9 \mathrm{~Hz}\right), 6.06\left(\mathrm{~d},=\mathrm{CH},{ }^{3} J_{\mathrm{H}-\mathrm{H}}=\right.$ $11.9 \mathrm{~Hz}) \cdot{ }^{13} \mathrm{C} \mathrm{NMR}\left(\mathrm{CDCl}_{3}\right): \delta 139.5(\mathrm{~s},-\mathrm{C}=\mathrm{C}-\mathrm{Ar}), 109.4(\mathrm{~s}$, $-C=\mathrm{C}-\mathrm{Ar}), 95.2(\mathrm{~s}, \mathrm{Ar}-C \equiv \mathrm{C}-), 89.6(\mathrm{~s}, \mathrm{Ar}-\mathrm{C} \equiv C-), 138.1$, $131.7,130.6\left(\mathrm{~d}, J_{\mathrm{F}-\mathrm{C}}=6.18 \mathrm{~Hz}\right), 130.1\left(\mathrm{~d}, J_{\mathrm{F}-\mathrm{C}}=6.18 \mathrm{~Hz}\right)$, $128.8,127.7,125.6(\mathrm{~m}), 125.3,122.2\left(\mathrm{~d}, J_{\mathrm{F}-\mathrm{C}}=12.7 \mathrm{~Hz}\right) . \mathrm{MS}$ $(\mathrm{FAB}, \mathrm{m} / \mathrm{z}): 340.0\left(\mathrm{M}^{+}\right)$. Compound $\mathbf{8 h}(44.3 \mathrm{mg})$ was similarly obtained in $25 \%$ yield from $1 \mathrm{~h}(177.5 \mathrm{mg}, 1.45 \mathrm{mmol})$. Spectroscopic data for $\mathbf{8 h}:{ }^{1} \mathrm{H}$ NMR $\left(\mathrm{CDCl}_{3}\right): \delta 7.89(\mathrm{~m}$, phenyl, $2 \mathrm{H}), 7.41(\mathrm{~m}, \mathrm{Ph}, 2 \mathrm{H}), 7.05(\mathrm{~m}, \mathrm{Ph}, 4 \mathrm{H}), 6.66\left(\mathrm{~d},=\mathrm{CH},{ }^{3} J_{\mathrm{H}-\mathrm{H}}\right.$ $=11.9 \mathrm{~Hz}), 5.87\left(\mathrm{~d},=\mathrm{CH},{ }^{3} J_{\mathrm{H}-\mathrm{H}}=11.9 \mathrm{~Hz}\right) . \mathrm{MS}(\mathrm{FAB}, \mathrm{m} / z)$ : $240.0\left(\mathrm{M}^{+}\right)$. Compound $8 \mathbf{i}(235.8 \mathrm{mg})$ was similarly obtained in $90 \%$ yield from $1 \mathbf{i}(262 \mathrm{mg}, 1.45 \mathrm{mmol})$. Spectroscopic data for 8i: ${ }^{1} \mathrm{H} \mathrm{NMR}\left(\mathrm{CDCl}_{3}\right): \delta 7.76\left(\mathrm{~d},{ }^{3} J_{\mathrm{H}-\mathrm{H}}=8.5 \mathrm{~Hz}\right), 7.51(\mathrm{~d}$, $\left.{ }^{3} J_{\mathrm{H}-\mathrm{H}}=8.6 \mathrm{~Hz}\right), 7.49\left(\mathrm{~d},{ }^{3} J_{\mathrm{H}-\mathrm{H}}=8.6 \mathrm{~Hz}\right), 7.32\left(\mathrm{~d},{ }^{3} J_{\mathrm{H}-\mathrm{H}}=8.5\right.$ $\mathrm{Hz}), 6.67\left(\mathrm{~d},=\mathrm{CH},{ }^{3} J_{\mathrm{H}-\mathrm{H}}=11.9 \mathrm{~Hz}\right), 5.93\left(\mathrm{~d},=\mathrm{CH},{ }^{3} J_{\mathrm{H}-\mathrm{H}}=\right.$ $11.9 \mathrm{~Hz}) .{ }^{13} \mathrm{C} \mathrm{NMR}\left(\mathrm{CDCl}_{3}\right): \delta 137.7(\mathrm{~s},-\mathrm{C}=C-\mathrm{Ar}), 107.9(\mathrm{~s}$, $-C=\mathrm{C}-\mathrm{Ar}$ ), $95.3(\mathrm{~s}, \mathrm{Ar}-C \equiv \mathrm{C}-), 88.9(\mathrm{~s}, \mathrm{Ar}-\mathrm{C} \equiv C-), 135.3$, 132.8, 131.7, 131.5, 130.2, 122.8, 122.5, 122.1 (all singlet, phenyl). MS (FAB, m/z): $361.8\left(\mathrm{M}^{+}\right)$. Compound 8j (115 mg) was similarly obtained in $35 \%$ yield from $\mathbf{1 j}$ (330 mg, 1.45 mmol). Spectroscopic data for $\mathbf{8 j}:{ }^{1} \mathrm{H} \mathrm{NMR}\left(\mathrm{CDCl}_{3}\right): \delta 7.71(\mathrm{~d}$, $\left.{ }^{3} J_{\mathrm{H}-\mathrm{H}}=8.14 \mathrm{~Hz}\right), 7.69\left(\mathrm{~d},{ }^{3} J_{\mathrm{H}-\mathrm{H}}=8.35 \mathrm{~Hz}\right), 7.61\left(\mathrm{~d},{ }^{3} J_{\mathrm{H}-\mathrm{H}}=\right.$ $8.35 \mathrm{~Hz}), 7.17\left(\mathrm{~d},{ }^{3} J_{\mathrm{H}-\mathrm{H}}=8.14 \mathrm{~Hz}\right), 6.63\left(\mathrm{~d},{ }^{3} J_{\mathrm{H}-\mathrm{H}}=11.9 \mathrm{~Hz}\right)$, $5.91\left(\mathrm{~d},{ }^{3} J_{\mathrm{H}-\mathrm{H}}=11.9 \mathrm{~Hz}\right) \cdot{ }^{13} \mathrm{C} \mathrm{NMR}\left(\mathrm{CDCl}_{3}\right): \delta 137.8(\mathrm{~s},-\mathrm{C}=$ $C-\mathrm{Ar}), 108.1(\mathrm{~s},-C=\mathrm{C}-\mathrm{Ar}), 95.7(\mathrm{~s}, \mathrm{Ar}-C \equiv \mathrm{C}-), 89.3(\mathrm{~s}, \mathrm{Ar}-$ $\mathrm{C} \equiv C-$ ), 137.6, 137.4, 135.8, 132.8, 130.3, 122.6, 94.6, 94.3 (all singlet, phenyl). MS (FAB, $\mathrm{m} / z)$ : $455.8\left(\mathrm{M}^{+}\right)$.

X-ray Analysis of $\mathbf{5 b}$. Single crystals of $\mathbf{5 b}$ suitable for an $\mathrm{X}$-ray diffraction study were grown by the methods described in the previous section. The diffraction data were collected on an Enraf-Nonius CAD4 diffractometer equipped with graphitemonochromated Mo $\mathrm{K} \alpha(\lambda=0.71037 \AA)$ radiation. Crystallographic computations were carried out using the NRCC-SDPVAX structure determination package. ${ }^{29}$ A suitable single crystal of $\mathbf{5 b}$ was mounted on the top of a glass fiber with glue. Initial lattice parameters were determined from 25 accurately centered reflections in the range from $15.70^{\circ}$ to $23.74^{\circ}$. Cell constants and other pertinent data are collected in Table 5. Data were collected using the $\theta-2 \theta$ scan method. The final scan speed for each reflection was determined from the net intensity gathered during an initial prescan and ranged from 2 to $8 \mathrm{deg} \min ^{-1}$. Merging equivalent and duplicate reflections

(29) (a) Gabe, E. J.; Lee, F. L.; Lepage, Y. In Crystallographic Computing 3; Shelldrick, G. M., Kruger, C., Goddard, R., Eds. Clarendon Press: Oxford, England, 1985; p 167. (b) International Tables for X-ray Crystallography; D. D. Reidel Pub. Co.: Dordrecht, 1974; Vol. IV. (c) LePage, Y.; Gabe, E. J. Appl. Crystallogr. 1990, 23, 406 .
Table 5. Crystal Data and Structure Refinement for $5 b$

\begin{tabular}{lll}
\hline empirical formula & $\mathrm{C}_{49} \mathrm{H}_{40} \mathrm{Cl}_{4} \mathrm{IN}_{2} \mathrm{O}_{3} \mathrm{P}_{2} \mathrm{Rh}$ & \\
fw & 1138.38 & \\
temperature & $295(2) \mathrm{K}$ & \\
wavelength & $0.71073 \AA$ & \\
cryst syst & triclinic & \\
space group & $P \overline{1}$ & $\alpha=77.06(2)^{\circ}$ \\
unit cell dimens & $a=12.915(2) \AA$ & $\AA=71.678(13)^{\circ}$ \\
& $b=13.210(3) \AA$ & $\gamma=66.88(2)^{\circ}$ \\
& $c=15.975(3) \AA$ & \\
volume, $Z$ & $2363.9(7) \AA^{3}, 2$ & \\
density (calcd) & $1.599 \mathrm{Mg} / \mathrm{m}^{3}$ & \\
absorp coeff & $1.352 \mathrm{~mm}^{-1}$ & \\
$F(000)$ & 1136 & \\
cryst size & $0.35 \times 0.30 \times 0.20 \mathrm{~mm}$ & \\
$\theta$ range for data & 1.69 to $24.97^{\circ}$ & \\
$\quad$ collection & $-13<h<15$, & \\
limiting indices & $0<k<15$, & \\
& $-18<l<18$ & \\
& $8309[I>2 \sigma(I): 5787]$ & \\
no. of independent & & \\
reflns & & \\
max. and min. transmn & 0.7785 and 0.6829 \\
refinement method & full-matrix least- \\
& $\quad$ squares on $F^{2}$ \\
no. of data/restraints/ & $8309 / 0 / 522$ \\
$\quad$ params & \\
goodness-of-fit on $F^{2}$ & 0.943 \\
final $R$ indices $[I>2 \sigma(I)]$ & $\mathrm{R} 1=0.0454$, \\
& $\mathrm{wR} 2=0.1301$ \\
$R$ indices (all data) & $\mathrm{R} 1=0.0738$, \\
& $\mathrm{wR} 2=0.1475$ \\
largest diff peak and & 1.065 and $-0.809 \mathrm{e} / \AA^{3}$ & \\
$\quad$ hole & &
\end{tabular}

gave a total of 8309 unique measured data in which 5787 were considered observed, $I>2 \sigma(I)$. The structure was first solved by using the heavy atom method (Patterson synthesis), which revealed the positions of metal atoms. The remaining atoms were found in a series of alternating difference Fourier maps and least-squares refinements. The quantity minimized by the least-squares program was $w\left(\left|F_{\mathrm{o}}\right|-\left|F_{\mathrm{c}}\right|\right)^{2}$, where $w$ is the weight of a given operation. The analytical forms of the scattering factor tables for the neutral atoms were used. The non-hydrogen atoms were refined anisotropically. Hydrogen atoms were included in the structure factor calculations in their expected positions on the basis of idealized bonding geometry but were not refined in least squares.

Acknowledgment. Financial support from the National Science Council, Taiwan, is gratefully acknowledged.

Supporting Information Available: Tables of crystal data collection, refinement parameters, atomic coordinates, bond lengths and angles, anisotropic displacement parameters, and hydrogen coordinates for $\mathbf{5 b}$. This material is available free of charge via the Internet at http://pubs.acs.org.

OM049604S 